\title{
1 An ecological status indicator for all time: Are AMBI and 2 M-AMBI effective indicators of change in deep time?

4 Bryony A. Caswel1*1, ${ }^{1,}$ Chris L. J. Frid ${ }^{3}$, Angel Borja ${ }^{4}$

$6{ }^{1}$ Environmental Futures Research Institute, Griffith University, Gold Coast, 7 Queensland 4222, Australia.

$8 \quad{ }^{2}$ School of Environmental Science, University of Hull, Hull, HU6 7RX, UK

$9{ }^{3}$ School of Environment and Science, Griffith University, Gold Coast, QLD 4222, 10 Australia.

$11{ }^{4}$ AZTI, Marine Research Division, Herrera Kaia Portualdea s/n, 20100 Pasaia, Spain

13 *Corresponding author: email; Phone: $+44(0) 1482466341$

\section{Abstract}

Increasingly environmental management seeks to limit the impacts of human activities on ecosystems relative to some 'reference' condition, which is often the presumed pre-impacted state, however such information is limited. We explore how

20 marine ecosystems in deep time (Late Jurassic)are characterised by AZTI's Marine 21 Biotic Index (AMBI), and how the indices responded to natural perturbations. AMBI

22 is widely used to detect the impacts of human disturbance and to establish 23 management targets, and this study is the first application of these indices to a fossil 24 fauna. Our results show AMBI detected changes in past seafloor communities (well25 preserved fossil deposits) that underwent regional deoxygenation in a manner 26 analogous to those experiencing two decades of organic pollution. These findings

27 highlight the potential for palaeoecological data to contribute to reconstructions of 28 pre-human marine ecosystems, and hence provide information to policy makers and 29 regulators with greater temporal context on the nature of 'pristine' marine 30 ecosystems. 
32 Key words: baseline; palaeoecology; deoxygenation; AMBI; environmental 33 monitoring; reference conditions 


\section{Introduction}

There is increasing recognition of the value of marine ecosystems, the services

37 they provide (Costanza et al., 2014; de Groot et al., 2012; United Nations, 2005) and

38 the threats to their continued delivery (United Nations 2017). Attempts to manage

39 these threats (e.g. pollution, fisheries, shipping, climate change (Breitburg et al.,

40 2018; FAO, 2016; Frid and Caswell, 2017; IPCC, 2014; United Nations, 2005)) have

41 often been hampered by a lack of clear information on the state of the system and how

42 this relates to the pressures imposed (Carpenter et al., 2009; Lubchenco and Petes,

43 2010). This has led to the development of a plethora of indices of "environmental

44 health' that seek to inform regulatory bodies and wider society about the state of the

45 environment and in turn support the management of impacting activities (Birk et al.,

46 2012; Borja et al., 2016; Niemi and McDonald, 2004).

47 In adopting an 'ecosystem approach' to environmental management many 48 jurisdictions have sought to incorporate metrics of 'system level' health/status within 49 their regulatory frameworks (e.g. EU, US, Canada)(Borja et al., 2008; Niemeijer and 50 de Groot, 2008; United Nations, 2005). However, finding indicators that are 'reliable' 51 (see ICES 2001a for a discussion of the properties of an ideal indicator) when applied 52 to systems other than those for which they were developed has proved challenging 53 (ICES, 2001b; Rice et al., 2012; Rice and Rochet, 2005; Rossberg et al., 2017; Van 54 Hoey et a. 2010).

Seafloor sediments represent the second largest habitat on Earth and those organisms that inhabit the seafloor (the benthos) are often monitored and used as the basis for assessments of marine ecosystem health (Díaz et al., 2004). The benthos tends to have high site fidelity and moderate (multiple year) longevity so that they

59 serve to integrate short-term fluctuations in environmental conditions, and so are 
60 representative of the local environmental status. They also occupy a critical role in 61 many marine food webs such as those upon which commercial fisheries depend.

62 These attributes of the benthos have been recognised for decades and the monitoring

63 of benthic fauna has been a key aspect of many estuarine and coastal monitoring

64 programs (e. g. Gray et al., 1990). One of the most widely applied measures of marine

65 benthic 'health' has been the AZTI's Marine Biotic Index (AMBI) family of indices

66 which were originally developed to measure the impacts of enrichment,

67 deoxygenation and pollution within estuaries and coastal waters (Borja et al., 2000).

68 Developed for the EU Water Framework Directive (European Commission 2000)

69 these metrics are now used for the remediation assessments in the Marine Strategy

70 Framework Directive (European Commission 2008, Borja et al. 2011). To form the

71 basis of a regulatory response both a strong response to pressures and an

72 understanding of the nature of the un-impacted or baseline system are needed.

73 The effects of these pressures on natural systems are hard to predict

74 (HELCOM, 2010) and require reference conditions or baselines for determining

75 change from what is normal or typical for an ecosystem (ICES, 2001a, b). Knowledge

76 of the undisturbed state of marine ecosystems, in terms of structure, functioning and

77 dynamics, are generally lacking and the data used within management frameworks are

78 rarely 'true' baselines in that they do not describe a state prior to anthropogenic

79 pressures (Jackson et al., 2001; Pauly, 1995). Although management baselines

80 describe the last few decades of change, they neglect the long history of marine

81 exploitation that spans centuries to millennia (Jackson et al., 2001; Lotze et al., 2006;

82 Pandolfi et al., 2003; Rick and Erlandson, 2008), some of the consequences of which

83 are yet to manifest (Jackson et al., 2001). The reliability of forecasting and the

84 evidence-base for management could be improved by a better appreciation of the 
reference conditions for anthropogenically-induced change (Van Hoey et al., 2010).

86 However, these baselines have been shown to shift with the temporally limited

87 knowledge-base of the observer, the baseline continually shifts to reflect a more and

88 more degraded state moving further from the 'natural' reference state (Dayton et al.,

89 1998; Kittinger et al., 2015; Pauly, 1995). The shifting baseline phenomenum makes

90 it difficult to discern natural from anthropogenic change, and can obscure long-term

91 change and natural variability (Klein and Thurstan, 2016).

92 To manage the pressures on marine ecosystems successfully there is a need to

93 understand the changes, natural and anthropogenic, which have occurred to date and

94 prepare for those that may occur in the future (Cheung et al., 2009; Pauly et al., 2000;

95 Pereira et al., 2010; Stock et al., 2011). Information on the nature of historic healthy

96 ecosystems and ecosystem resilience is needed to determine reliable targets (Lotze,

97 2010). This information can be acquired from environmental history (Klein and

98 Thurstan, 2016), but whilst being an improvement over more recent 'baseline data',

99 these reference conditions still incorporate some degree of anthropogenic impact (e. g.

100 Pinnegar and Engelhard, 2008). Using the fossil record of ecological change (or

101 'palaeoecological' change) allows consideration of the ecosystem prior to human

102 activities. Although the taxa present differ, to some degree, they occupy very similar

103 ecological niches and have equivalent ecological roles (Caswell and Frid, 2013).

104 These palaeoassemblages therefore have the potential to provide ecological and

105 functional baselines for 'pristine' seafloor communities, and may also provide

106 reference conditions for regional and global perturbations within coastal ecosystems

107 that were driven by wholly natural processes (e.g. volcanism, plate tectonics, clathrate

108 dissociation, or wildfires)(Bond and Grasby, 2017; e. g. Jenkyns, 2010). In this study

109 we investigate the record of regional palaeoecological change from Late Jurassic 
110 deposits of the Kimmeridge Clay Formation in Dorset, UK, as an example of changes

111 in coastal benthic systems experiencing natural organic enrichment and associated

112 deoxygenation.

113 This study examines whether disturbances in past marine ecosystems can be

114 measured using biotic indices developed to assess contemporary ecosystem status

115 under human disturbance. In principle, benthic community indices such as AMBI and

116 M-AMBI (Muxika et al., 2007) should reflect environmental changes (e.g.

117 deoxygenation, and climate) whether they be natural or human induced (Borja et al.,

118 2015). We test whether relatively well-preserved fossil deposits that have undergone

119 substantial natural environmental (as indicated by geochemical and geological

120 proxies) and ecological changes are analogous to the changes occurring in the modern

121 oceans in response to anthropogenic activities. To date, these indices have only been

122 applied to assemblages of live taxa and recently to death assemblages ((i.e. skeletal

123 components only) of molluscs that have great potential value for benthic assessments

124 (Dietl et al., 2016; Leshno et al., 2016), however they have not previously been

125 applied to fossil assemblages.

126

\section{2. Methods}

\section{2.1. Study site and data sources}

129 Data for this study originate from the sedimentary deposits of the Kimmeridge

130 Clay Formation (KCF) that are exposed in the south-east UK on the Dorset coast near

131 Kimmeridge, UK $\left(50^{\circ} 36^{\prime} 58^{\prime \prime} \mathrm{N}, 2^{\circ} 7^{\prime} 14^{\prime}\right.$ 'W), Westbury pit, south Wiltshire and Black

132 Head near Osmington and Weymouth (Fig. 1). The formation consists of up to $\sim 540$

$133 \mathrm{~m}$ of vertical section of cyclically alternating fine grained organic-rich sediments and

134 limestones (Morgans-Bell et al., 2001). The total organic carbon content (TOC) of the 
135 deposits is very high at some levels (up to $\sim 50 \mathrm{wt} \%$ ) and the stratigraphy and

136 geochemistry have been well-studied (e. g. Morgans-Bell et al., 2001; Tyson, 2004;

137 van Kaam-Peters et al., 1997). The palaeoassemblage data analysed in the present

138 study are based on the species composition and abundance data (number, expressed as

139 percentage, per $0.2 \mathrm{~m}^{3}$ of rock sampled) collected by Wignall $(1988,1990)$ from these

140 exposures of the KCF. Samples were collected approximately every $1 \mathrm{~m}$ vertically

141 throughout the section and were classified into 31 unique associations on the basis of

142 their ranked species-abundance distributions (sensu Wignall, 1990), hereafter referred

143 to as palaeoassemblages, many of which recur throughout the stratigraphic section

144 (Supplementary Material (SM) Fig. S1). The palaeoassemblages spanned between

$1450.05 \mathrm{~m}-24.4 \mathrm{~m}$ of vertical rock and so persisted on average for $0.90 \mathrm{~m}$ equivalent to a

146 temporal duration of $\sim 7000$ years based on the cyclostratigraphic timescale of

147 Weedon et al. (2004), totalling around 4 million years.

148 On the other hand, a contemporary data set has been used to compare the

149 response of the benthic assemblages to environmental changes. We have used data

150 from the Nervión estuary (North of Spain), which has been modified by urban,

151 mining, industrial and port settlement; these have occupied practically the whole of

152 the valley, during the last 150 years (Cearreta et al., 2004). The estuary received

153 historically high volumes of wastewater discharges, resulting in extremely low

154 concentrations of dissolved oxygen in the waters and high organic matter and

155 pollution content, leading to deterioration of benthic communities (Borja et al., 2006).

156 Reductions in the volumes of wastewater discharged began in the late 1980s, the

157 physico-chemical waste treatment began in 1991, and biological treatment started in

1582001 (Pascual et al., 2011). Data on the benthic macrofaunal composition, oxygen and

159 organic matter in the Nervión estuary were obtained from a monitoring program 
160 carried out since 1989 (Borja et al., 2006). In order to have two contrasting benthic

161 assemblages, we selected two out of the eight sampling stations with differing levels

162 of enrichment: (i) station 5, located in the inner part of the estuary, in a water depth of

$1638-10 \mathrm{~m}$ near to the discharge point; and, (ii) station 110 , close to estuary mouth, in

$16425-30$ m water depth. Data for these two stations span 1989 to 2012.

\section{2. $A M B I$ and $M-A M B I$ determination}

167 One of the challenges in assessing the status of palaeoecological assemblages

168 is the assignation of species to one of the five ecological groups (EG) on which AMBI

169 is based: EGI: sensitive species; EGII: indifferent species; EGIII: tolerant to organic

170 enrichment; EGIV: second order opportunistic species; and EGV: first order

171 opportunistic species (Borja et al., 2000). The ecological group classifications

172 consider feeding type, life habit, body-size, life history and response to disturbances

173 (i.e. organic enrichment)(Borja et al. 2000). This information may be acquired for a

174 fossil fauna by: direct measurement, functional morphology, use of extant analogues,

175 and the associations of fossil taxa (i.e. determined from distribution and/or

176 abundance, nature of the palaeoenvironmental and the palaeoecological associations).

177 In the SM we have included the complete list of taxa, with the feeding type, life habit,

178 body-size, mode of reproduction, distribution, associations and the source literature,

179 for each taxon, upon which we have based the assignation of the ecological groups

180 (Table S1). To avoid circular reasoning each taxa was classified using independent

181 evidence (Table S1), which shows the response of the taxa to environmental

182 disturbances. After taxa assignation to ecological groups, AMBI values were

183 calculated using the formula in Borja et al. (2000), with the software available at

184 http://ambi.azti.es. The threshold values used for AMBI classification were: 
undisturbed $<1.2$; slightly disturbed 1.2-3.3; moderately disturbed, 3.3-5.0; heavily disturbed 5.0-6.0; and extremely disturbed 6.0-7.0.

The M-AMBI determination included information on the ecological groups (from $\mathrm{AMBI}$ ), taxa richness and diversity, and it uses information from both undisturbed and severely disturbed communities as reference conditions to assess biological status. For the undisturbed reference conditions an AMBI value of zero was used (total dominance of sensitive species), and for richness and diversity values that were slightly higher than the highest values in the dataset (55 for taxonomic richness and 4.5 bits ind $^{-1}$ for diversity). Conversely, the disturbed reference conditions were selected using azoic sediments with an AMBI value of 6 (extremely disturbed) and for richness and diversity we used zero.

M-AMBI was calculated using the same software as for AMBI, based on factor analysis (Bald et al., 2005; Muxika et al., 2007). At 'high' ecological status, the reference condition may be regarded as an optimum where the M-AMBI approaches 1, whilst at 'bad' ecological status, the M-AMBI approaches 0 . The threshold values used for the M-AMBI classification were 'high' ecological quality, >0.77; 'good', 0.53-0.77; 'moderate', 0.38-0.53; 'poor', 0.20-0.38; and 'bad', $<0.20$ (Borja et al., 2007; 2009).

\subsection{Relationships between environmental conditions and biotic indices}

The links between the changes in the AMBI and M-AMBI score of the palaeoassemblages from Kimmeridge (21 of the total 31$)$ were investigated using data on the TOC and the ratio of the elemental abundances of Thorium: Uranium $(\mathrm{Th} / \mathrm{U})$, measured from bulk rock samples, collected from the Kimmeridge Clay Formation exposed on the coast (i.e. the same sections as those from which the palaeontological 
210 data were collected) and two nearby boreholes sections (Morgans-Bell et al., 2001;

211 Fig. 1b). TOC may be indicative of organic carbon supply to the benthos, and so 212 primary production (e. g. Tyson, 2004) and/or redox state. The elemental ratio of

213 Thorium: Uranium $(\mathrm{Th} / \mathrm{U})$ abundances may be a proxy for palaeoredox (Arthur and

214 Sageman, 1994; Morgans-Bell et al., 2001). The relationships between the indices,

215 and between the biotic indices and environmental factors/proxies for

216 palaeoenvironmental change were determined using Spearman's rank order

217 correlation or linear regression.

219 3. Results

\section{3.1. The palaeoassemblages}

221 The palaeoassemblages included a total of 129 taxa, mostly true species, with taxa

222 richness of the individual assemblages varying between six and 42. The assemblages

223 were dominated by bivalve molluscs, but also contained gastropods, brachiopods,

224 bryozoans, crustaceans, scaphopods, echinoderms and annelids (serpulid worms). AMBI

225 showed that the 31 palaeoassemblages ranged from 'slightly' to 'heavily disturbed'

226 (Table 1, Fig. 2a). Two palaeoassemblages were heavily disturbed (E1a and E2a), 14

227 were moderately disturbed and the remaining 15 were slightly disturbed (Table 1). In

228 turn, M-AMBI showed that the ecological status of the assemblages varied from 'bad'

229 to 'good' (Table 1, Fig. 2b) with one assemblage having bad ecological status (E2a),

230 six poor, six moderate and the remaining 18 were good, with two (A7 and A10) near

231 the boundary of good-high status (Fig. 2b). Thus, classifications of the 31

232 palaeoassemblages by AMBI and M-AMBI differed, and overall M-AMBI described

233 a broader range of states than AMBI. The results from the two indices classified

234 palaeoassemblages A1, A10, A11 and E3 as being of better state (based on their 
235 relative groupings with the other palaeoassemblages; Table 1) with M-AMBI rather

236 than AMBI, whereas E9 and A5 received a lower classification with M-AMBI (Table

237 1). These differences in classification seemed to be primarily attributable to

238 differences between the number of taxa present in the assemblages, which are used in

239 the determination of M-AMBI but not AMBI (Fig. 2?).

240 The 31 palaeoassemblages were composed of varying proportions of the five 241 ecological groups (Fig. 2). Under high TOC (e.g. $>4 \%$ ) for most palaeoassemblages $242 \geq 50 \%$ of the taxa were first and second order opportunists (ecological groups $\mathrm{V}$ and 243 IV, respectively; Fig. 2). E4 and E9 were exceptional in having both high TOC and 244 lower proportions of first and second order opportunists (Fig. 2c). Of the lower TOC $245(<4 \%)$ palaeoassemblages B1-B5 were dominated by disturbance-tolerant taxa 246 (ecological group III) with relatively equal proportions of taxa from the other four 247 ecological groups. Palaeoassemblages A2-A9 and A/E1 were composed mostly of 248 taxa that were indifferent to disturbance, disturbance-tolerant and second order 249 opportunists: with $<3 \%$ of taxa being first order opportunists. Assemblages A1 and 250 A10-A11 were similar to A2-A9 and A/E1, but had larger proportions of first order 251 opportunists. Assemblages E3, E8 and A7 had the highest proportions of taxa that 252 were sensitive to disturbance (Fig. 2).

253 Linear regression showed that both the AMBI and M-AMBI scores of the 21 254 palaeoassemblages from the outcrops near Kimmeridge were correlated with the 255 mean TOC content of the deposits within which each palaeoassemblage was 256 preserved (AMBI $\mathrm{R}^{2}=0.22, \mathrm{p}<0.05 ; \mathrm{M}-\mathrm{AMBI} \mathrm{R}^{2}=0.52, \mathrm{p}<0.001$; Fig. 3). Once E2a, 257 considered an outlier, was removed both correlations became stronger (AMBI $\mathrm{R}^{2}=$ $2580.25, \mathrm{p}<0.05 ;$ M-AMBI $\left.\mathrm{R}^{2}=0.64, \mathrm{p}<0.001\right)$. AMBI was also correlated $\left(\mathrm{R}^{2}=0.22\right.$, $259 \mathrm{p}<0.05)$ with mean $\mathrm{Th} / \mathrm{U}$ suggesting a direct or indirect link with palaeoredox. 
260 Amongst all palaeoassemblages E2a is unique in being dominated $>90 \%$ by first order

261 opportunists (Fig. 2) and having the highest AMBI and the lowest M-AMBI scores

262 suggesting heavy disturbance (although it does not have the highest TOC; Fig. 2c).

263 For the remaining 10 palaeoassemblages (A2-A11), collected from locations

264 other than Kimmeridge Bay, TOC and Th/U data were not available but AMBI values

265 indicated slight disturbance and M-AMBI indicated good ecological status for A2-

266 A9; and, A10-A11 were moderately disturbed although had good M-AMBI status

267 (Table 1). Palaeoassemblage A5 had distinctly higher AMBI and lower M-AMBI

268 (Fig. 2a) than the other 9 palaeoassemblages and was dominated, $>80 \%$, by second

269 order opportunists (Isocyprina spp.; Fig. 2a). A comparison of the abundances of the

270 different ecological groups (I-V) in the palaeoassemblages from Kimmeridge with

271 those from the other two sites (Weymouth and Westbury) showed that the mean

272 abundance of first order opportunists were five times more abundant at Kimmeridge

273 (t-test, $\mathrm{t}=2.54, \mathrm{p}=0.017$ ) than for the 10 palaeoassemblages from the other two sites 274 combined.

\subsection{Comparison of palaeoassemblages with present-day benthos}

277 The palaeoassemblages from the KCF were compared with the benthos of the

278 Nervión estuary between 1989 and 2016 (Table 1, Figs 2 and 4-5) that has received

279 human waste (sewage and industrial discharges) for $>150$ years and so has

280 experienced large organic loads (Figs 4-5). The Nervión assemblages ranged between

281 slightly and extremely disturbed within the inner reaches, and from undisturbed to

282 slightly disturbed in the outer reaches of the estuary (Table 1). Furthermore, the

283 assemblages in the inner reaches of the Nervión estuary remained disturbed (Table 1;

284 Fig. 4e) for a number of years despite improvements in oxygenation. 
The species richness of the palaeoassemblages were comparable with the

286 benthos from the Nervión estuary which ranged from $0-50$ species per site (Figs 2c, $2874 \mathrm{c}, 5 \mathrm{c})$. With the exception of palaeoassemblages E2a, E8 and A6-A7, the KCF 288 benthos most closely resembled those present in the inner reaches at Nervión after 2892001 when oxygen saturation increased from $50 \%$ to $>80 \%$ (Figs 1 and 3 ). In most 290 years these assemblages ranged from slightly to moderately disturbed (with good291 high M-AMBI status in the inner reaches; Figs 1a-c and 3a, Table 1). At times the 292 entire assemblage in the inner reaches of the estuary consisted of 2-3 species of first 293 order opportunists only, whereas in the KCF this was never the case (although some 294 barren possibly azoic intervals occurred; Wignall 1988, Figs 2 and 4). The most 295 disturbed palaeoassemblage E2a resembled those in the inner reaches of the Nervión 296 estuary prior to the initiation of physico-chemical water treatment in 1991 (Figs 1 and 297 3) where bottom water oxygen concentrations were $<40 \%$ saturation (Figs $4 b-c$ ).

298 Contrastingly, in the outer reaches of the Nervión estuary bottom water oxygen saturation exceeded $\sim 80 \%$ in all years (Fig. 5) and the range of AMBI scores 300 were approximately three-fold lower than those from the inner reaches (Figs $4 \mathrm{a}$ and 301 5a). These assemblages were classified as either undisturbed or slightly disturbed 302 (Table 1) and in most years $>70 \%$ of taxa were sensitive or indifferent to disturbance 303 (Figs $4 \mathrm{a}$ and 5a). Thus, overall the palaeoassemblages were more similar to the 304 benthos of the inner reaches of the estuary in terms of their AMBI, M-AMBI and 305 ecological group composition (Figs 2, 4 and 5). However, E8 and A6-A7 had more 306 similar ecological group composition and AMBI scores (although lower M-AMBI 307 scores) to the benthos in the outer reaches, being mostly composed of ecological 308 groups I-III, from 1989-1990 before water treatment began. In general, the KCF 309 palaeoassemblages seem to have been less disturbed than the benthos within the inner 
310 reaches of the Nervión estuary, but they were not as healthy as the benthos inhabiting

311 the outer reaches of the estuary.

312 The AMBI scores of assemblages from the inner reaches of the Nervión

313 estuary were strongly negatively correlated $\left(\mathrm{R}^{2}=0.75, \mathrm{p}<0.001\right)$ and the M-AMBI

314 were positively correlated $\left(\mathrm{R}^{2}=0.78, \mathrm{p}<0.001\right)$ with bottom water oxygen saturation.

315 In the outer reaches of the estuary the environmental gradients were less distinct (Fig.

316 5) and only the M-AMBI score was correlated with dissolved oxygen concentrations

$317\left(\mathrm{R}^{2}=0.20, \mathrm{p}<0.05\right)$. Although no direct relationship with oxygen content can be

318 established for the KCF palaeoassemblages the correlations between M-AMBI and

319 AMBI with TOC and Th/U shows there were at least indirect links between the

320 degree of ecological disturbance and palaeoredox conditions (Fig. 3).

321 Comparisons of the ecological group composition, AMBI, and M-AMBI

322 scores of palaeoassemblages from Westbury and Weymouth, for which there are no

323 geochemical proxy data, with sites in the Nervión estuary (Figs 1-4, Table 1)

324 provides some basis for interpretation of the palaeoenvironment. Palaeoassemblages

325 A10-A11 were comparable with those present in the inner reaches of the estuary

326 when full water treatment began (in 2001), and A2-A5 were comparable to the

327 benthos a decade or so afterwards (Figs $2 \mathrm{a}-\mathrm{b}$ and $4 \mathrm{a}-\mathrm{b}$ ) and so seem to have been less

328 enriched/deoxygenated. Palaeoassemblages A6-A7 were most similar to the benthos

329 in the outer reaches of estuary in 1989-1990 (before water treatment began) and so

330 although they may have received some organic enrichment they were also well-

331 oxygenated (Figs $2 \mathrm{a}-\mathrm{c}$ and $5 \mathrm{a}-\mathrm{e}$ ).

332 The relationships between AMBI, M-AMBI scores and species richness were

333 similar for the present-day and Jurassic datasets (Fig. 6a-c) and correlations were

334 stronger for the present-day data (Fig. 6a-c) perhaps because of preservational loss 
335 from the fossil assemblages. The nature of the relationship (i.e. the slope) between

336 species richness and M-AMBI varied for each dataset, an equivalent increase in M-

337 AMBI corresponded to a greater increase in species richness in the KCF and the outer

338 reaches of the estuary compared with the inner reaches. These differences are

339 probably attributable to environmental differences (with station 5 being upriver and so

340 in a different salinity regime and thus less diverse even when 'recovered' from the 341 organic enrichment).

342 The abundances of all ecological groups except one were correlated with both

343 AMBI and M-AMBI at station 5 and in the KCF (Table 2, $<<0.005$ ). For AMBI all

344 correlations were negative except for the first order opportunists (EG V) and for M-

345 AMBI the opposite was the case. At station 110 taxa that were sensitive or indifferent

346 decreased whereas second order opportunists increased with AMBI score $(\mathrm{p}<0.05)$;

347 and, the abundances of sensitive and indifferent taxa (EG I-II) were correlated with

348 M-AMBI $(\mathrm{p}<0.01)$.

349 Although the benthic diversity of the KCF is comparable with the Nervión

350 estuary (Figs 1b, 3b, 4b), the generally weaker correlations for the palaeofauna 351 compared with the present-day benthos (Fig. 6a-c) may indicate preservational loss 352 from the fossil assemblages. The weaker correlations between AMBI and species 353 richness (Fig. 6c) and the ecological group abundances (Table 2) might be due to a 354 lack of soft-bodied first and second order opportunists (EG IV-V) such as polychaetes 355 with low preservation potential.

\subsection{Temporal changes}

358 Throughout the c. 4 million years the majority of taxa were second order 359 opportunists (Fig. 7), followed by first order opportunists, tolerant taxa, and those that 360 were indifferent or sensitive to enrichment formed the smallest proportions. 
361 Comparison of the AMBI, M-AMBI and ecological group composition with the

362 benthic assemblages in the outer reaches of the Nervión estuary (Figs 5-6) that were

363 mostly normoxic show how the palaeoassemblages compared with a typical present-

364 day undisturbed benthos. These changes corresponded to fluctuations in the TOC of

365 the sedimentary deposits with periods of higher TOC generally having a greater

366 proportion of first order opportunists and periods of low TOC having more tolerant

367 (EG III), indifferent (EG II) and sensitive taxa (EG I). As time progressed there were

368 fewer second order opportunists, and taxa that were tolerant, indifferent or sensitive

369 became a larger proportion of the benthic assemblage (Fig. 7a). AMBI showed a

370 general decrease and M-AMBI an increase through time (Fig. 7b-c) suggesting that

371 conditions improved from being heavily to moderately disturbed (AMBI; Fig. 7b) or

372 from moderate to good ecological status (M-AMBI; Fig. 7c). 


\section{Discussion}

To continue accessing the ecosystem services that marine systems provide we need to effectively manage impacts of anthropogenic pressures up on ecosystems (United Nations, 2005). To do so requires an understanding of the ecosystem changes that have occurred in the past in order to prepare for those that may occur in the future under continuing human pressures (Cheung et al., 2009; Elliott et al., 2015; Pereira et al., 2010; Stock et al., 2011). Our understanding of the (human) pressure - (ecosystem) state relationship is hampered by the quality of our ecosystem baselines most of which are not truly natural (Dauvin and Ruellet, 2009; Elliott and Quintino, 2007; Jackson et al., 2001; Klein and Thurstan, 2016; Pauly, 1995). In this study we applied contemporary biotic indices of ecosystem health to fossil assemblages during a period of past natural environmental change in order to compare the ecological response and determine whether such palaeontological records have utility as wholly natural baselines for changes in the marine benthos. One hundred and fifty million years ago organic enrichment, caused by changes in regional ocean circulation patterns (Miller, 1990)(Fig. 1c-d), drove palaeoecological change in much the same way that anthropogenic organic enrichment does locally and regionally today (e. g. Caswell et al. 2018; Diaz and Rosenberg, 1995; Diaz and Rosenberg, 2008; Pearson and Rosenberg, 1978; Rabalais et al., 2010; Seitz et al., 2009; Sturdivant et al., 2014). While these changes are attributable to entirely natural processes they represent discrete and severe environmental events, and therefore might be seen as excursions from what we define as 'healthy baseline conditions'.

Overall, the palaeocommunities from the Late Jurassic Kimmeridge Clay Formation, UK were considered to be 'disturbed' using the benthic community health indices AMBI and M-AMBI that were developed for assessing the response of present- 
398 day benthic assemblages (e. g. Borja et al., 2000). Changes in the palaeoassemblages as

399 described by the two indices were correlated with the total organic carbon content

400 (TOC) of the sedimentary deposits: at higher TOC both AMBI and M-AMBI indicated

401 greater disturbance. Above 4\% sedimentary TOC AMBI classified communities as at

402 least 'moderately disturbed', and M-AMBI as 'moderate' or 'poor' ecological status.

403 Under the Water Framework Directive (European Commission, 2000) present-day

404 benthic communities classified as in moderate ecological status (e.g. M-AMBI $<0.53$, in

405 Spain), or worse, require remediation action (European Commission, 2018). So these

406 communities were perturbed, by natural events, and the severe organic enrichment

407 triggered changes in the benthos that were analogous to those seen in organically-

408 polluted modern systems (e. g. Birchenough and Frid, 2009; Borja et al., 2006; Caswell

409 et al. 2018; Diaz and Rosenberg, 2008; Pearson and Rosenberg, 1978; Rees et al.,

410 2006). This confirms that whilst the species inventory was completely different between

411 the Jurassic and the present-day, the ecology, life history and other taxa attributes were

412 comparable and responded in the same way. This suggests that periods in deep time for

413 which the indices report healthy/good status could potentially serve as true 'baselines'

414 for the assessment of marine environmental health (if preservational loss is also

415 considered).

416 Within the palaeoecological time series the decrease in M-AMBI and AMBI

417 status through time (Fig. 7) corresponded with an increasingly arid climate, shifting

418 from humid to semi-arid, that developed across the Laurasian continent approximately

$4194.5 \mathrm{Myr}$, after/above the base of the KCF (in the huddlestoni ammonite Zone; Hesselbo

420 et al., 2009; Wignall and Ruffell, 1990). Further confirming the utility of the AMBI

421 indices to identify periods of changing ecological 'health' and hence their potential for 
422 use in constructing baselines or reference configurations, such as those required for 423 climate change scenarios e.g. due to shifts in aridity (IPCC, 2013).

424 Comparisons with data from benthic assemblages in the inner and outer reaches 425 of the formerly polluted Nervión estuary in Bilbao, Spain (Borja et al., 2006) provided 426 further basis for the interpretation of the prevailing palaeoenvironmental conditions. 427 The palaeoecological group composition and the AMBI and M-AMBI scores in the 21 428 palaeoassemblages from Kimmeridge Bay when compared with the benthos from the 429 inner reaches of the Nervión estuary (Borja et al., 2006) showed that palaeocommunities $430 \mathrm{~A} / \mathrm{E} 1, \mathrm{~A} 1, \mathrm{~B} 1-\mathrm{B} 5$ and E8 had some organic enrichment but were probably oxygenated 431 for considerable periods (Fig. 2). Whereas the palaeoassemblages with high AMBI 432 scores $(>3.3)$ and low M-AMBI scores $(<0.53)$ were disturbed and regularly 433 deoxygenated (Fig. 2a, E1a-E7) which is consistent with the geochemical proxy data 434 that show elevated organic enrichment and deoxygenation (Fig. 2d)(Morgans-Bell et al., 435 2001; Pearce et al., 2010). Some discrepancies existed between AMBI and M-AMBI 436 scores (usually higher classifications with M-AMBI), presumably due to differences in 437 species richness (Borja et al., 2007), but overall the assessments of past ecological 438 status were consistent with previous interpretations for most of the Kimmeridge Bay 439 palaeoassemblages (Caswell and Frid, 2013; Wignall, 1990). The exception was E8, an 440 assemblage classified as deoxygenated by Wignall (1990) with a relatively high TOC 441 (3.8\%) (Morgans-Bell et al. 2000), indicating the AMBI/M-AMBI scores only 'slight 442 disturbance' or 'good' status, with an ecological group composition similar to 443 assemblages in the outer Nervión estuary. However, palaeoassemblage E8 also had a 444 unique taxonomic and biological trait composition compared with all of the other 445 palaeoassemblages (Caswell and Frid 2013). 
Although there were no environmental proxy data for palaeocommunities A2-

447 A11, documented from locations other than Kimmeridge Bay, the interpretation of their 448 oxygenation state based on the lithology (rock type) of the deposits (Wignall 1988) is 449 consistent with most of the AMBI and M-AMBI scores and ecological group 450 representation that indicated slight disturbance in A2 to A9. Moderate disturbance in 451 A10-A11 as suggested by Wignall (1988), based on the presence of several suspected 452 hypoxia tolerant taxa, is confirmed by AMBI (Fig. 2a-c). However, palaeoassemblage 453 A5, dominated by the second order opportunist Isocyprina spp. (Fürsich and Thomsen, 454 2005), had AMBI and M-AMBI scores (Fig. 2a) indicative of moderate disturbance and 455 poor ecological status which conflicts with its interpretation as oxygenated by Wignall 456 (1988).

457 Overall, the most impoverished palaeoassemblage was E2a that was classified as 458 being of bad ecological status and heavily disturbed, E2a was comprised of $>90 \%$ first 459 order opportunists although it did not have exceptionally high TOC (Fig. 2d)(Morgans460 Bell et al., 2001). This palaeoassemblage was not unusual in taxonomic or biological 461 trait composition (Caswell and Frid, 2013) although it was dominated by opportunistic 462 bivalves and conditions were sometimes euxinic (Pearce et al., 2010).

463 The organic enrichment and deoxygenation recorded in the Kimmeridge Clay 464 Formation resulted in significant changes in the composition of the marine benthos. For 465 example, decreased species richness, the disappearance of echinoderms, crustacean and 466 scaphopods, reductions in burrowing depth (Caswell and Frid 2013), and increased 467 proportions of first and second order opportunists. However, none of the 468 palaeocommunities were classified as being extremely disturbed (AMBI $>6$ ), 469 completely undisturbed (AMBI $\leq 1.2)$, or of high ecological status $(\mathrm{M}-\mathrm{AMBI}>0.77)$.

470 There are several possible explanations for this: 
(i) That the benthic conditions remained sub-optimal throughout the entire $3 \mathrm{Myr}$

472 period. The geochemical proxies showed that regional deoxygenation persisted between

4732.4 to $5.6 \mathrm{Myr}$ (Fig. 7a)(Pearce et al., 2010), and these regional changes were 474 accompanied by global increases in the intensity of reducing conditions at that time 475 (Pearce et al., 2010) increasing the likelihood for local/regional deoxygenation to 476 develop.

477 (ii) The M-AMBI reference conditions and the boundaries between quality 478 classes, used for this data may have been inadequate and need refining (Birk et al., 479 2013) since the boundaries were established for contemporary benthic communities 480 (Borja et al., 2012).

481 (iii) Alternatively, this could be an artefact of incomplete preservation (e. g. 482 Behrensmeyer et al., 2000), which biased species composition and so the AMBI and M483 AMBI classifications. Although fossil assemblages can reliably be used to reconstruct 484 palaeoassemblage diversity and composition, among other attributes, this potential 485 varies between groups of taxa (Greenstein, 2007; Kidwell, 2013; Miller, 2011; Terry, 486 2010). For instance, Kidwell and Tomasovych (2013) and Kidwell (2015) showed that 487 the fidelity of fossil and subfossil death assemblages with living shelled fauna is very 488 good, with $83-95 \%$ site and $75-98 \%$ habitat fidelity. However, it seems unlikely that 489 there were so few soft-bodied taxa in the palaeocommunity, such as polychaetes that 490 form a significant component of modern healthy and enriched benthic assemblages 491 (Diaz and Rosenberg, 1995; Levin, 2003; Rees et al., 2006). For instance, in the inner 492 reaches of the Nervión estuary the "Capitella capitata" species complex dominated, 493 however in the outer reaches Tellina and Venus bivalves dominated (Borja et al., 2006). 494 Soft-bodied taxa such as polychaetes have low preservation potential and are often 495 under-represented in the geological record (Briggs, 2003). The inclusion of information 
496 on trace fossils that record organism behaviour, e.g. tracks, burrows or resting traces,

497 could provide information on the extent and nature of the missing fauna, and its

498 contribution to ecosystem functioning (e. g. Caswell and Frid, 2017). Unfortunately,

499 detailed information is lacking for the KCF at the present time.

500 (iv) The final reason that the scores for the palaeoassemblages and the

501 undisturbed contemporary benthos in the outer reaches of the Nervión estuary may

502 differ is due to time averaging. A degree of time-averaging is inherent to almost all

503 fossil, or subfossil, assemblages, information might be averaged over weeks, years,

504 centuries or millennia. The samples from Nervión were collected annually whereas an

505 individual sampling point in the Kimmeridge Clay represents a period that approximates

506 a century (based on the timescale of Weedon et al. 2004). These temporal differences

507 may result in short-term variations becoming obscured (Kidwell and Tomasovych

508 2013), and the greater period of time represented by the palaeoassemblages may have

509 inflated the apparent species richness above that in the original life assemblages

510 (Kidwell, 2013). Although the differences in timescale must be considered in any

511 comparison with the present-day fauna, time-averaging can capture superior

512 information, than that from non time-averaged data, and this includes information on

513 rare species, regional diversity, species range changes, habitat preferences, and species

514 turnover(Kidwell and Tomasovych, 2013; Kidwell 2015).

515

516 AMBI has previously been applied to both whole benthic assemblages and

517 selected taxonomic groups, such as polychaetes (Cheung et al., 2008) or molluscs (Dietl

518 et al., 2016; Leshno et al., 2016; Nerlovic et al. 2011). A recent meta-analysis (Dietl et

519 al. 2016) showed that analyses of partial assemblages, i.e. the mollusc component only,

520 share many features with death assemblages, and so this is a viable method for 
521 determining changes in ecological status. The AMBI scores of death assemblages and

522 mollusc-only assemblages were comparable with those for complete live assemblages

523 (in $\sim 80 \%$ of cases the AMBI ecological status assignments were the same; Dietl et al.

524 2016). This suggests that, even if the Kimmeridge assemblage was incomplete, the

525 results probably do not differ much from those expected if the fossil assemblage was

526 complete (Dietl et al. 2016, Leshno et al. 2016). Dietl et al. (2016) showed that partial

527 assemblages, i.e. of molluscs only, slightly overestimated the AMBI values for

528 assemblages with high ecological status and underestimated AMBI for those with low

529 ecological status: this might explain the lack of Kimmeridge assemblages classified as

530 being extremely disturbed (AMBI $>6)$.

Comparison of contemporary faunas with palaeoassemblages from a greater

533 range of palaeoenvironments (as determined from lithology and geochemical proxies)

534 and/or from those that are exceptionally preserved e. g. Lagerstätte (e.g. the Solnhofen

535 limestone (Barthel et al., 1990), Burgess Shale (Conway Morris, 1998) or Chengiiang

536 Maotianshan Shales (Hou et al., 1999)) will help to determine whether the differences in

537 AMBI and M-AMBI values between present-day and the fossil assemblages are

538 environmental or preservational. Such work would also supply valuable ecological

539 information required to establish better baselines for ecosystem state prior to human

540 disturbance, and so will help refine the reference conditions used by tools such as

541 AMBI (Borja et al., 2012, Dietl et al. 2016). Study of naturally perturbed (i.e. pre-

542 human) systems can improve understanding of pressure-impact relationships such as

543 functional changes and ecological threshold-effects (Birk et al., 2012; Caswell and Frid,

544 2013; Frid and Caswell, 2015). Furthermore, death assemblages whether fossils or

545 subfossil, may provide an integrated temporal picture, as opposed to the snapshots 
546 usually acquired by ecologists, that is more likely to describe the ecological status of a

547 region. Such information is sorely needed (Van Hoey et al., 2010) and could be a great 548 asset for defining the thresholds of 'good environmental status' upon which regulation 549 is implemented (e.g. European Commission 2008, Dietl et al. 2016, Leshno et al. 2016).

This study has shown that even when applied to marine benthic assemblages

552 from deep time that contain no species in common with modern systems, and those that 553 underwent wholly natural ecological change the AMBI indices are able to distinguish 554 between perturbed and unperturbed systems. This in turn allows for both a fuller 555 analysis of the impacts of large-scale 'natural' perturbations that are analogous to 556 systems subjected to anthropogenic pressures, and/or those that will be impacted in the 557 future (IPCC, 2014; United Nations, 2005). It also highlights the potential of 558 palaeoecological datasets more generally for developing reconstructions of past 559 community structure and functioning in pre-human marine ecosystems (e. g. Caswell 560 and Frid, 2013; Caswell and Frid, 2017; Dietl et al., 2015; Kidwell, 2013). In this way 561 palaeoecological data could provide information to policy makers and environmental 562 regulators with greater temporal context that reveals the true or 'pristine' nature of 563 marine ecosystems prior to human impacts.

\section{5. Conclusions}

566 The AMBI and M-AMBI indices, are extensively used in many countries across 567 the World to assess benthic habitat quality in response to a range of different human 568 pressures (Borja et al., 2015). Organic enrichment and deoxygenation during the Late 569 Jurassic, although natural, produced considerable changes in the ecological structure 570 and functioning of benthic palaeocommunities that could be detected using the AMBI 
571 and M-AMBI indices. Despite the considerable differences in temporal scale, these

572 changes were consistent with the response of the present-day benthos to organic

573 enrichment and deoxygenation in the inner and outer reaches of the polluted Nervión

574 estuary in Bilbao, Spain. We have shown that the application of biotic indices, such as

575 these, to palaeontological data could be used to (i) provide information on reference

576 conditions and for the structure and functioning of benthic communities prior to human

577 impacts that could be used to determine "good ecological status"; and (ii) help identify

578 and/or confirm the ecological impacts of past perturbations (in Earth history) on marine

579 benthos, by comparison with indices from present-day systems, particularly when

580 palaeoenvironmental information is missing or incomplete.

\section{Acknowledgements}

583 Infrastructure and support were provided by the Environmental Futures Research

584 Institute, School of Environment, Griffith University, the University of Hull, AZTI and

585 Consorcio de Aguas Bilbao-Bizkaia. 
Arthur, M.A., Sageman, B.B., 1994. Marine black shales: depositional mechanisms and environments of ancient deposits. Annual Review of Earth and Planetary Sciences 22, 499-551.

Barthel, K.W., Swinburne, N.H.M., Conway Morris, S., 1990. Solnhofen: A study in Mesozoic palaeontology. Cambridge Univeristy Press.

Behrensmeyer, A.K., Kidwell, S.M., Gastaldo, R.A., 2000. Taphonomy and paleobiology. Paleobiology 26, 103-147.

Birchenough, S.N.R., Frid, C.L.J., 2009. Macrobenthic succession following the cessation of sewage sludge disposal. Journal of Sea Research 62, 258-267.

Birk, S., Bonne, W., Borja, A., Brucet, S., Courrat, A., Poikane, S., Solimini, A., van de Bund, W., Zampoukas, N., Hering, D., 2012. Three hundred ways to assess Europe's surface waters: An almost complete overview of biological methods to implement the Water Framework Directive. Ecological Indicators 18, 31-41.

Birk, S., Willby, N.J., Kelly, M.G., Bonne, W., Borja, A., Poikane, S., van de Bund, W., 2013. Intercalibrating classifications of ecological status: Europe's quest for common management objectives for aquatic ecosystems. Science of The Total Environment 454-455, 490-499.

Bond, D.P., Grasby, S.E., 2017. On the causes of mass extinctions. Palaeogeography, Palaeoclimatology, Palaeoecology 478, 3-29.

Borja, A., Bricker, S.B., Dauer, D.M., Demetriades, N.T., Ferreira, J.G., Forbes, A.T., Hutchings, P., Jia, X., Kenchington, R., Marques, J.C., Zhu, C., 2008. Overview of integrative tools and methods in assessing ecological integrity in estuarine and coastal systems worldwide. Marine Pollution Bulletin 56, 1519-1537.

Borja, Á., Dauer, D.M., Grémare, A., 2012. The importance of setting targets and reference conditions in assessing marine ecosystem quality. Ecological Indicators $12,1-7$.

Borja, A., Elliott, M., Andersen, J.H., Berg, T., Carstensen, J., Halpern, B.S., Heiskanen, A.-S., Korpinen, S., Lowndes, J.S.S., Martin, G., Rodriguez-Ezpeleta, N., 2016. Overview of integrative assessment of marine systems: the Ecosystem Approach in practice. Frontiers in Marine Science 3, doi: 10.3389/fmars.2016.00020.

Borja, A., Franco, J., Pérez, V., 2000. A marine biotic index to establish the ecological quality of soft-bottom benthos within European estuarine and coastal environments. Marine Pollution Bulletin 40, 1100-1114.

Borja, A., Franco, J., Valencia, V., Bald, J., Muxika, I., Jesus Belzunce, M., Solaun, O., 2004. Implementation of the European water framework directive from the Basque country (northern Spain): a methodological approach. Marine Pollution Bulletin 48, 209-218.

Borja, A., Josefson, A.B., Miles, A., Muxika, I., Olsgard, F., Phillips, G., Rodríguez, J.G., Rygg, B., 2007. An approach to the intercalibration of benthic ecological status assessment in the North Atlantic ecoregion, according to the European Water Framework Directive. . Marine Pollution Bulletin 55, 42-52.

Borja, Á., Marín, S.L., Muxika, I., Pino, L., Rodríguez, J.G., 2015. Is there a possibility of ranking benthic quality assessment indices to select the most responsive to different human pressures? . Marine Pollution Bulletin 97, 85-94.

Borja, A., Muxika, I., Franco, J., 2006. Long-term recovery of soft-bottom benthos following urban and industrial sewage treatment 
in the Nervión estuary (southern Bay of Biscay). Marine Ecology Progress Series 43, 43-55.

Breitburg, D., Levin, L.A., Oschlies, A., Grégoire, M., Chavez, F.P., Conley, D.J., Garçon, V., Gilbert, D., Gutiérrez, D., Isensee, K., Jacinto, G.S., Limburg, K.E., Montes, I., Naqvi, S.W.A., Pitcher, G.C., Rabalais, N.N., Roman, M.R., Rose, K.A., Seibel, B.A., Telszewski, M., Yasuhara, M., Zhang, J., 2018. Declining oxygen in the global ocean and coastal waters. Science 359, 1-13.

Briggs, D.E.G., 2003. The role of deacy and mineralization in the preservation of soft-bodied fossils. Annual Review of Earth and Planetary Sciences 31, 275-301.

Carpenter, S.R., Mooney, H.A., Agard, J., Capistrano, D., Defries, R.S., Diaz, S., Dietz, T., Duraiappah, A.K., Oteng-Yeboah, A., Pereira, H.M., Perrings, C., Redi, W.V., Sarukhan, J., Scholes, R.J., Whyte, A., 2009. Science for mapping ecosystem services: Beyond the Millennium Ecosystem Assessment. Proceedings of the National Academy of Science 106, 1305-1312.

Caswell, B.A., Frid, C.L.J., 2013. Learning from the past: functional ecology of marine benthos during eight million years of aperiodic hypoxia, lessons from the Late Jurassic. Oikos 122, 1687-1699.

Caswell, B.A., Frid, C.L.J., 2017. Marine ecosystem resilience during extreme deoxygenation: the Early Jurassic oceanic anoxic event. Oecologia 183, 275-290.

Caswell, B.A., Paine, M., Frid, C.L.J. 2018. Seafloor functioning over two decades of organic enrichment. Marine Pollution Bulletin 136, 212-229.

Cheung, S. G., N. W. Y. Lam, R. S. S. Wu, P. K. S. Shin, 2008. Spatio-temporal changes of marine macrobenthic community in sub-tropical waters upon recovery from eutrophication. II. Life-history traits and feeding guilds of polychaete community. Marine Pollution Bulletin, 56: 297-307.

Cheung, W.W.L., Lam, V.W.Y., Sarmiento, J.L., Kearney, K., Watson, R., Pauly, D., 2009. Projecting global marine biodiversity impacts under climate change scenarios. Fish and Fisheries 10, 235-251.

Conway Morris, S., 1998. The Crucible of Creation: The Burgess Shale and the Rise of Animals. Oxford University Press.

Costanza, R., de Groot, R., Sutton, P., van der Ploeg, S., Anderson, S.J., Kubiszewski, I., Farber, S., Turner, R.K., 2014. Changes in the global value of ecosystem services. Global Environmental Change 26, 152-158.

Dauvin, J.-C., Ruellet, T., 2009. The estuarine quality paradox: Is it possible to define an ecological quality status for specific modified and naturally stressed estuarine ecosystems? . Marine Pollution Bulletin 59, 38-47.

Dayton, P.K., Tegner, M.J., Edwards, P.B., Riser, K.L., 1998. Sliding baselines, ghosts and reduced expectations in kelp forest communities. Ecological Applications 8, 309-322.

de Groot, R., Brander, L., van der Ploeg, S., Costanza, R., Bernard, F., Braat, L., Christie, M., Crossman, N., Ghermandi, A., Hein, L., Hussain, S., Kumar, P., McVittie, A., Portela, R., Rodriguez, L.C., ten Brink, P., van Beukering, P., 2012. Global estimates of tje value of ecosystems and their services in monetary units. Ecosystem Services 1, 50-61.

Diaz, R.J., Rosenberg, R., 1995. Marine benthic hypoxia: a review of its ecologcial effects and the behavioural responses of benthic macrofauna, in: Ansell, A. (Ed.), Oceanography and Marine Biology Annual Review. University College London Press, London, UK, pp. 245-303.

Diaz, R.J., Rosenberg, R., 2008. Spreading dead zones and consequences for marine ecosystems. Science 321, 926-929. 
Díaz, R.J., Solan, M., Valente, R.M., 2004. A review of approaches for classifying benthic habitats and evaluating habitat quality. Journal of Environmental Management 73, 165-181.

Dietl, G.P., Kidwell, S.M., Brenner, M., Burney, D.A., Flessa, K.W., Jackson, S.T., Koch, P.L., 2015. Conservation paleobiology: Leveraging knowldege of the past to inform conservation and restoration. Annual Review of Earth and Planetary Sciences 43, 79-103.

Dietl, G. P., S. R. Durham, J. A. Smith, A. Tweitmann, 2016. Mollusk Assemblages As Records of Past and Present Ecological Status. Frontiers in Marine Science, 3: 10.3389/fmars.2016.00169.

Elliott, M., Borja, Á., McQuatters-Gollop, A., Mazik, K., Birchenough, S., Andersen, J.H., Painting, S., Peck, M., 2015. Force majeure: Will climate change affect our ability to attain Good Environmental Status for marine biodiversity? . Marine Pollution Bulletin 95, 7-27.

Elliott, M., Quintino, V., 2007. The Estuarine Quality Paradox, environmental homeostasis and the difficulty of detecting anthropogenic stress in naturally stressed areas. Marine Pollution Bulletin 54, 640-645.

European Commission. 2000. Directive 2000/60/EC of the European Parliament and of the Council of 23 October 2000 establishing a framework for community action in the field of water policy (Water Framework Directive). Official Journal of the European Union L327, 1-72.

European Commission. 2008. Directive 2008/56/EC of the European Parliament and of the Council of the council establishing a framework for community action in the field of marine environmental policy (Marine Strategy Framework Directive). Official Journal of the European Union L164, 19-40.

European Commission, 2018. Commission Decision (EU) 2018/229 of 12 February 2018 establishing, pursuant to Directive 2000/60/EC of the European Parliament and of the Council, the values of the Member State monitoring system classifications as a result of the intercalibration exercise and repealing Commission Decision 2013/480/EU. Official Journal of the European Communities, L47: 1-91.

FAO, 2016. The state of the World's fisheries and aquaculture 2016. Contributing to food security and nutrition for all, Food and Agriculture Organisation of the United Nations, Rome.

Frid, C.L.J., Caswell, B.A., 2015. Is long-term ecological functioning stable: The case of the marine benthos? Journal of Sea Research 98, 15-23.

Frid, C.L.J., Caswell, B.A., 2017. Marine Pollution. Oxford University Press, Oxford.

Fürsich, F.T., Thomsen, E., 2005. Jurassic biota and biofacies in erratics from the Sortland area, Vesterålen, northern Norway. . Norges Geologiske Undersøkelse Bulletin 443, 37-53.

Gray, J.S., Clarke, K.R., Warwick, R.M., Hobbs, G., 1990. Detecting the initial effects of pollution on marine benthos - an example from the Ekofisk and Eldfisk oilfields, North Sea. Marine Ecology Progress Series 66, 285-299.

Greenstein, B.J., 2007. Taphonomy, detecting critical events in fossil reef coral assemblages, in: Aronson, R.B. (Ed.), Geological approaches to croal reef ecology. Springer, New York, pp. 31-60.

HELCOM, 2010. Towards a tool for quantifying anthropogenic pressures and potential impacts on the Baltic Sea marine environment: A background document on the method, data and testing of the Baltic Sea Pressure and Impact Indices, Baltic Sea Environmental Proceedings, pp. 1-72. 
Table 1. AMBI and M-AMBI classifications for the 31 Late Jurassic benthic palaeoassemblages (from the Kimmeridge Clay Formation), and comparison with the benthic assemblages from the different years in the inner and outer reaches of the Nervión estuary, Bilbao, Spain (from 1989-2016).

\begin{tabular}{|c|c|c|c|}
\hline \multirow{2}{*}{ Classification } & \multicolumn{3}{|c|}{ Benthic assemblages } \\
\hline & Kimmeridge Clay Fm & Nervión estuary: inner & Nervión estuary: outer \\
\hline \multicolumn{4}{|l|}{ AMBI: } \\
\hline Undisturbed & & & $92,97-98,01,04,06-08$ \\
\hline Slightly disturbed & $\begin{array}{l}\text { A/E1, A2-A4, A6-A9, } \\
\text { B1-B5, E8-E9 }\end{array}$ & $03-04,06,09-10$ & $\begin{array}{l}89-96,99-00,02-03,05 \\
09-12\end{array}$ \\
\hline Moderately disturbed & $\begin{array}{l}\text { A1, A5, A10-A11, } \\
\text { E1b, E2b-E2e, E3-E7 }\end{array}$ & $\begin{array}{l}98,01,05,07-08,11- \\
12\end{array}$ & \\
\hline Heavily disturbed & E1a, E2a & 90-97, 99-00 & \\
\hline Extremely disturbed & & 89 & \\
\hline \multicolumn{4}{|l|}{ M-AMBI: } \\
\hline High & & $03-06,09-12$ & $89-04,06-12$ \\
\hline Good & $\begin{array}{l}\mathrm{A} / \mathrm{E} 1, \mathrm{~A} 1-\mathrm{A} 4, \mathrm{~B} 1-\mathrm{B} 5 \\
\mathrm{E} 3, \mathrm{E} 8, \mathrm{~A} 6-\mathrm{A} 11\end{array}$ & $02,07-08$ & 05 \\
\hline Moderate & E2b-E2d, E4-E5, E9 & 98 & \\
\hline Poor & $\begin{array}{l}\text { A5, E1a-E1b, E2e, } \\
\text { E6-E7 }\end{array}$ & $00-01$ & \\
\hline Bad & E2a & $89-97$ & \\
\hline
\end{tabular}


Table 2. Correlations between ecological group (ecol. group) abundance and AMBI, or M-AMBI for all three datasets. Empty cells $=$ no significant correlation $(\mathrm{p}>0.05)$. Ecological group classifications: $\mathrm{I}=$ taxa sensitive to disturbance, $\mathrm{II}=$ taxa indifferent to disturbance, III = disturbance-tolerant taxa, IV = second order opportunists, $\mathrm{V}=$ first order opportunists.

\begin{tabular}{|c|c|c|c|c|c|c|}
\hline \multirow{2}{*}{$\begin{array}{c}\text { Ecol. } \\
\text { group }\end{array}$} & \multicolumn{3}{|c|}{ AMBI } & \multicolumn{3}{c|}{ M-AMBI } \\
\cline { 2 - 7 } & KCF & Station 5 & Station 110 & KCF & Station 5 & Station 110 \\
\hline I & $-0.37, \mathrm{p}<0.001$ & $-0.60, \mathrm{p}<0.001$ & $-0.76, \mathrm{p}<0.001$ & $0.20, \mathrm{p}<0.05$ & $0.97, \mathrm{p}<0.001$ & $0.31, \mathrm{p}<0.01$ \\
\hline II & $-0.57, \mathrm{p}<0.001$ & $-0.43, \mathrm{p}<0.001$ & & $0.15, \mathrm{p}<0.05$ & $0.59, \mathrm{p}<0.001$ & $-0.51, \mathrm{p}<0.005$ \\
\hline III & $-0.17, \mathrm{p}<0.05$ & $-0.57, \mathrm{p}<0.001$ & $-0.60, \mathrm{p}<0.001$ & $0.31, \mathrm{p}<0.005$ & $0.44, \mathrm{p}<0.001$ & \\
\hline IV & $0.20, \mathrm{p}<0.05$ & $-0.43, \mathrm{p}<0.001$ & $0.22, \mathrm{p}<0.05$ & & $0.37, \mathrm{p}<0.005$ & \\
\hline V & $0.49, \mathrm{p}<0.001$ & $0.59, \mathrm{p}<0.001$ & & $-0.37, \mathrm{p}<0.001$ & $-0.58, \mathrm{p}<0.001$ & \\
\hline
\end{tabular}


Figure 1
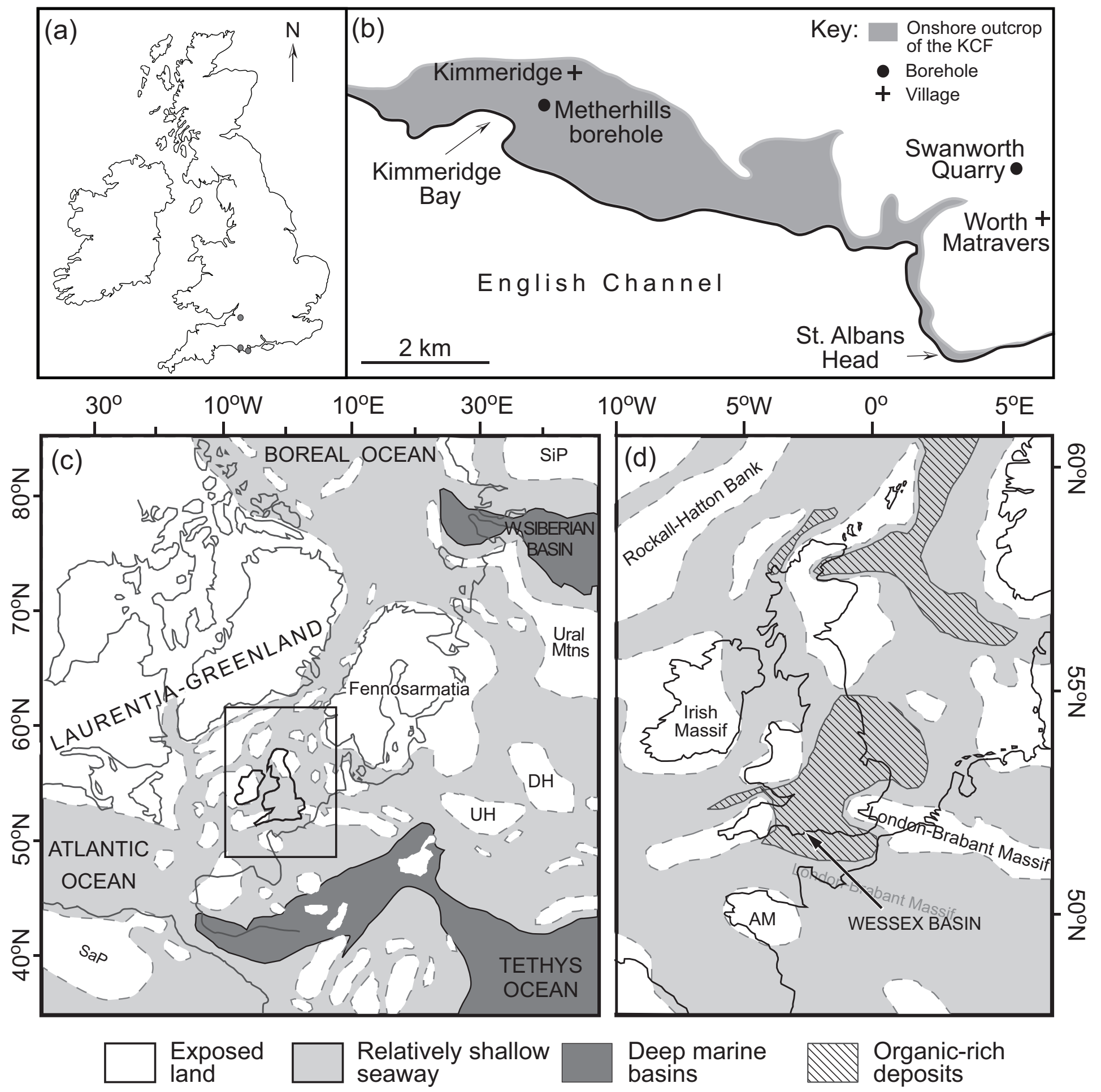

Fig. 1 Caswell, Frid, Borja 2018 
Figure 2 black and white

Ecol. groups:

(a)

\section{II}

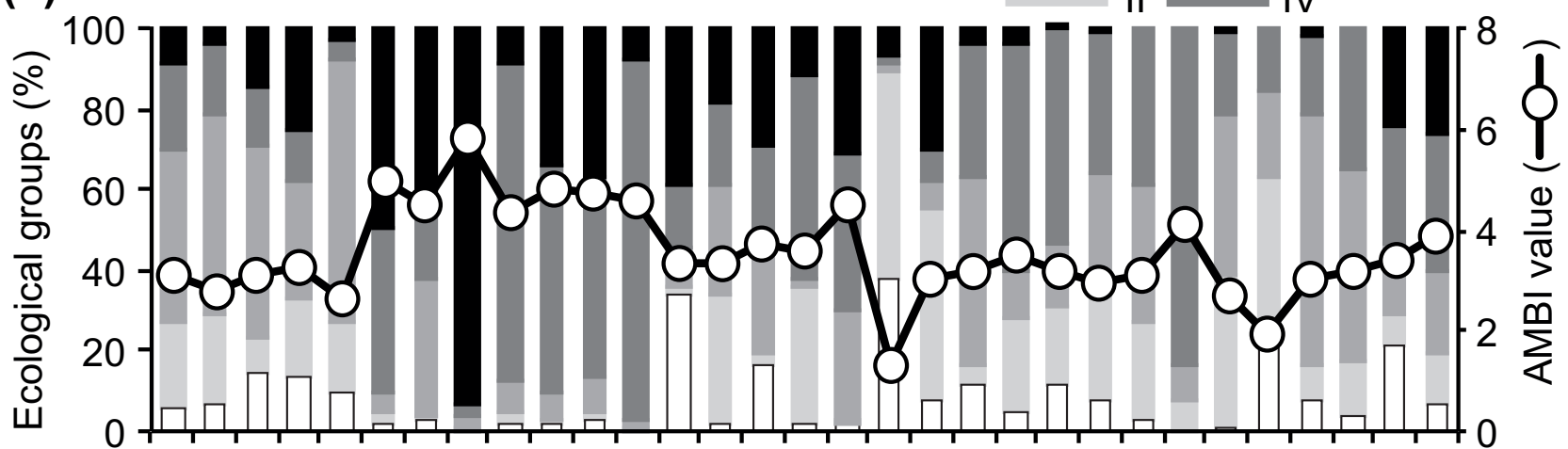

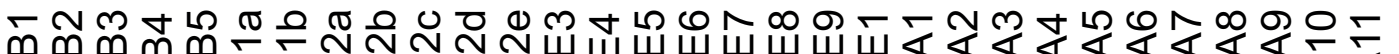

(b)

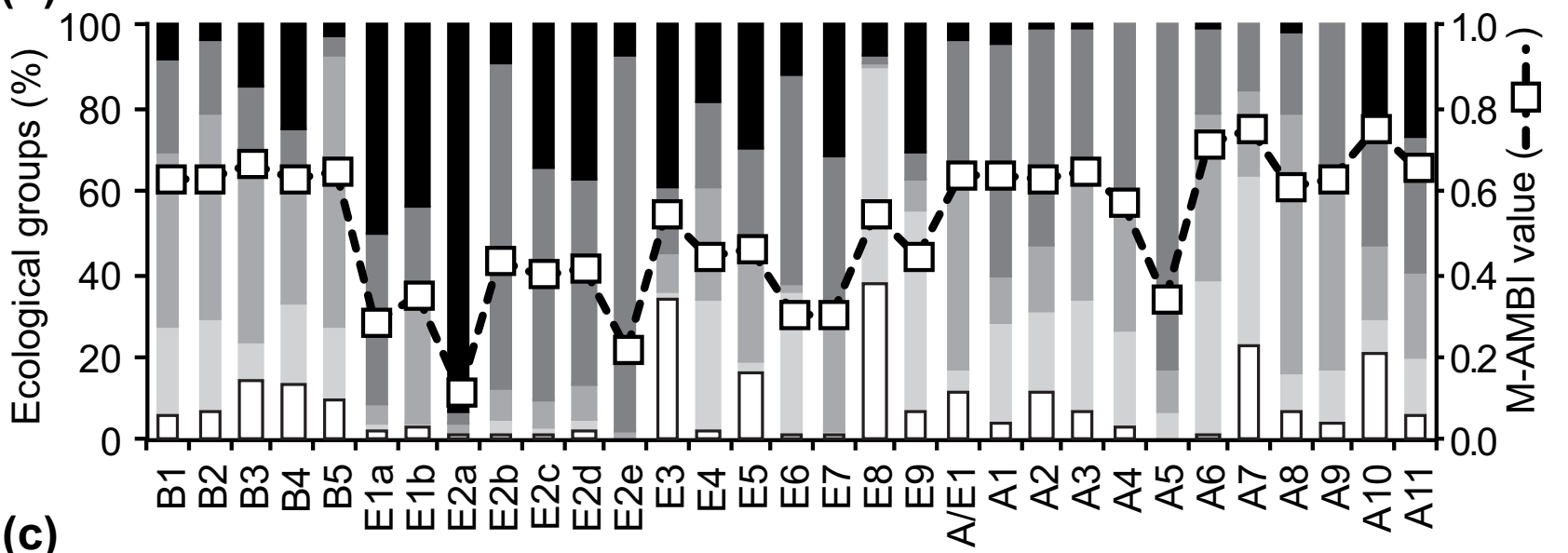

(c)

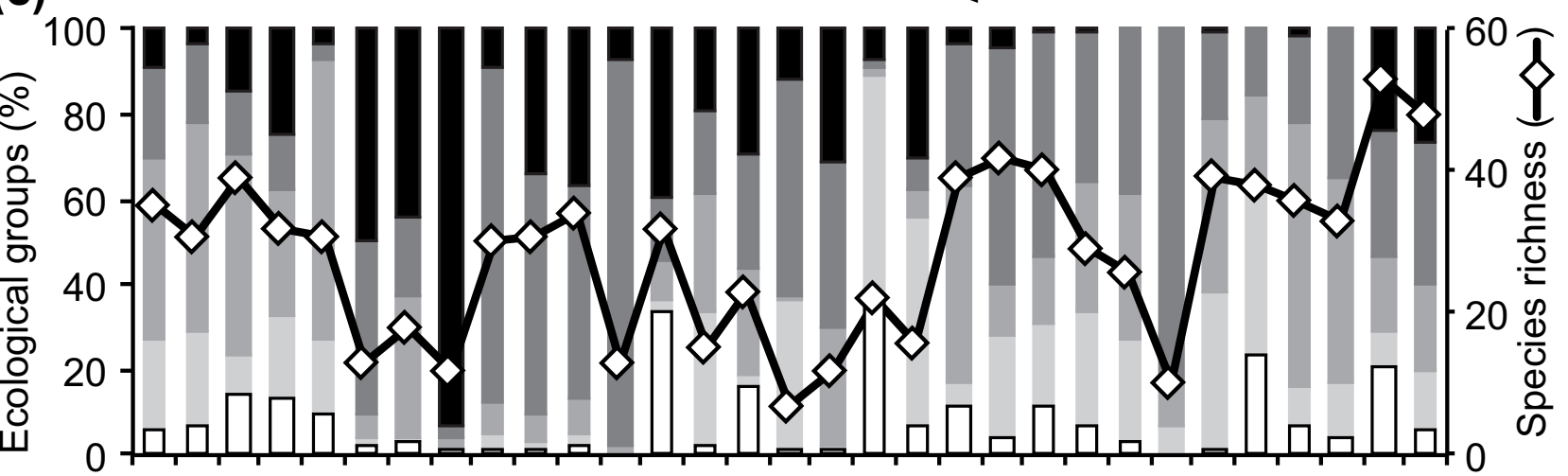

(d)

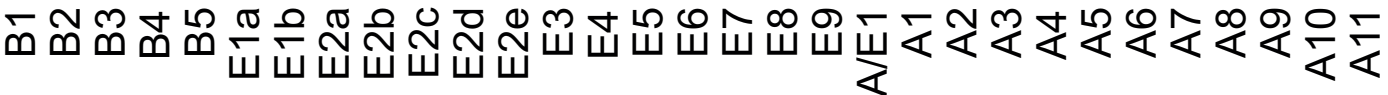

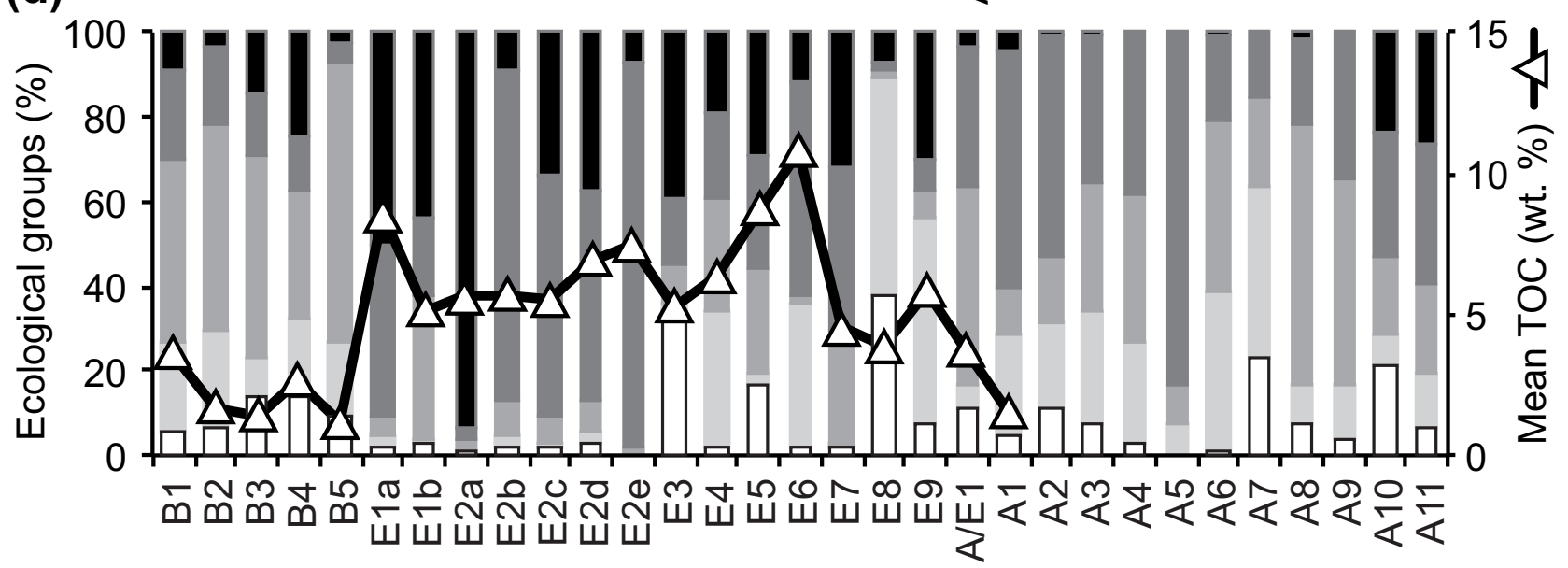

Caswell, Frid, Borja 2018 Figure 2 black and white 
Figure 2 colour (online only)

(a)

Ecol. groups:
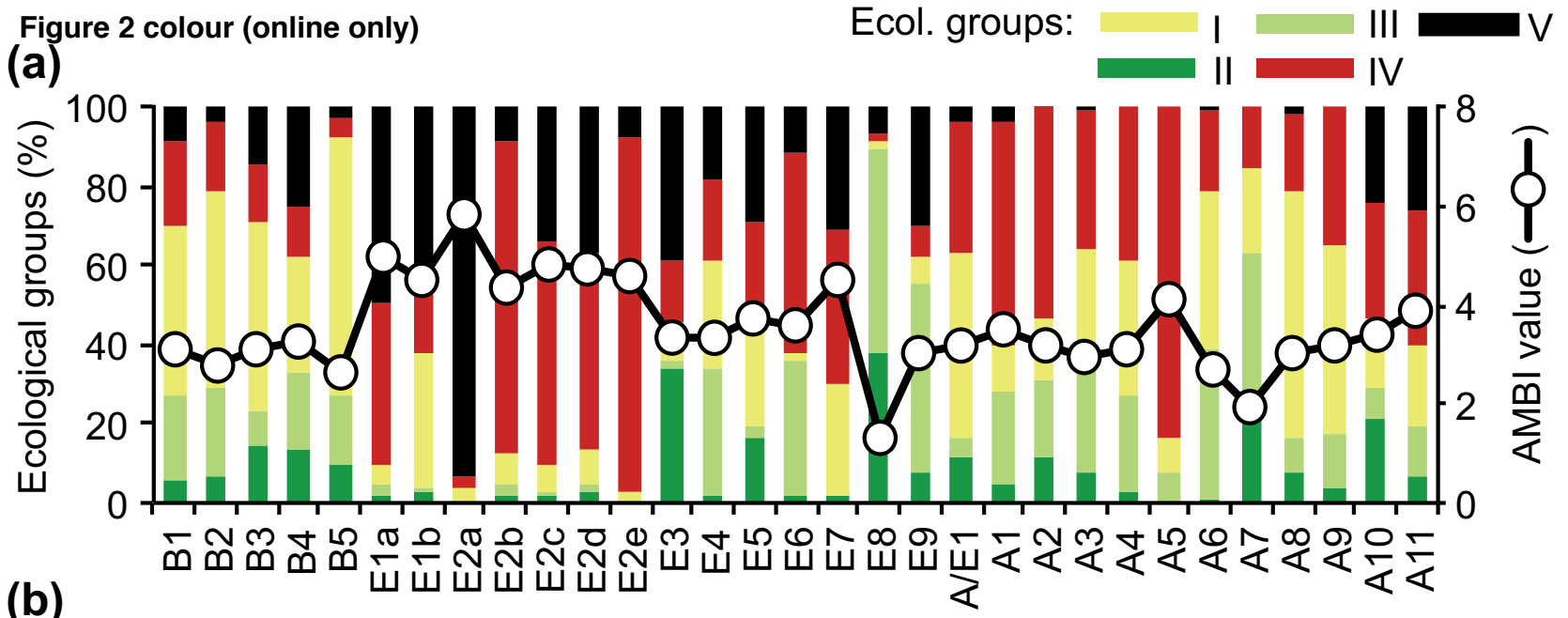

(b)

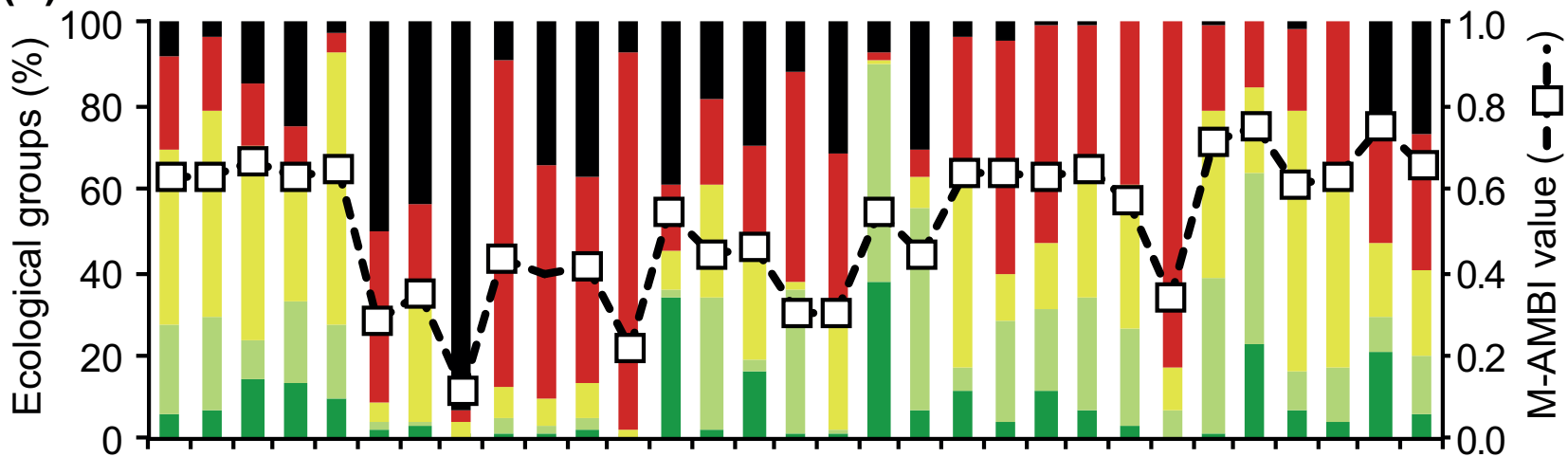

(c)

ธே๊ ๓

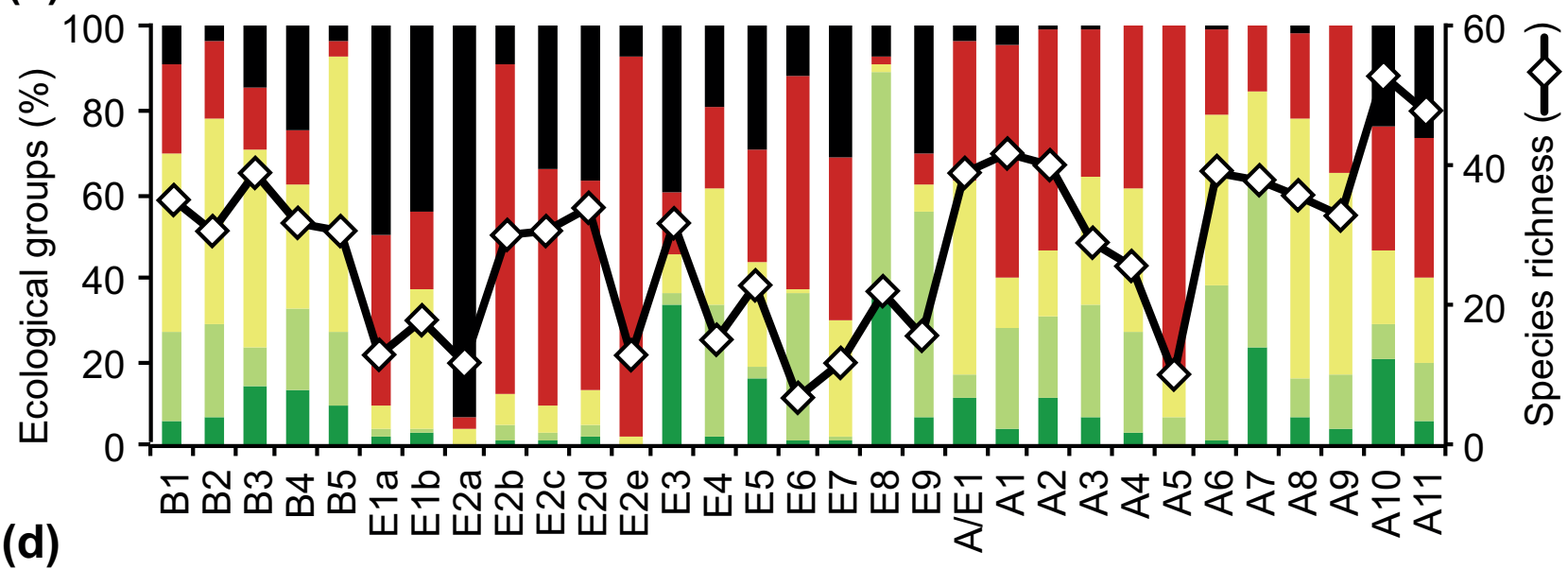

के

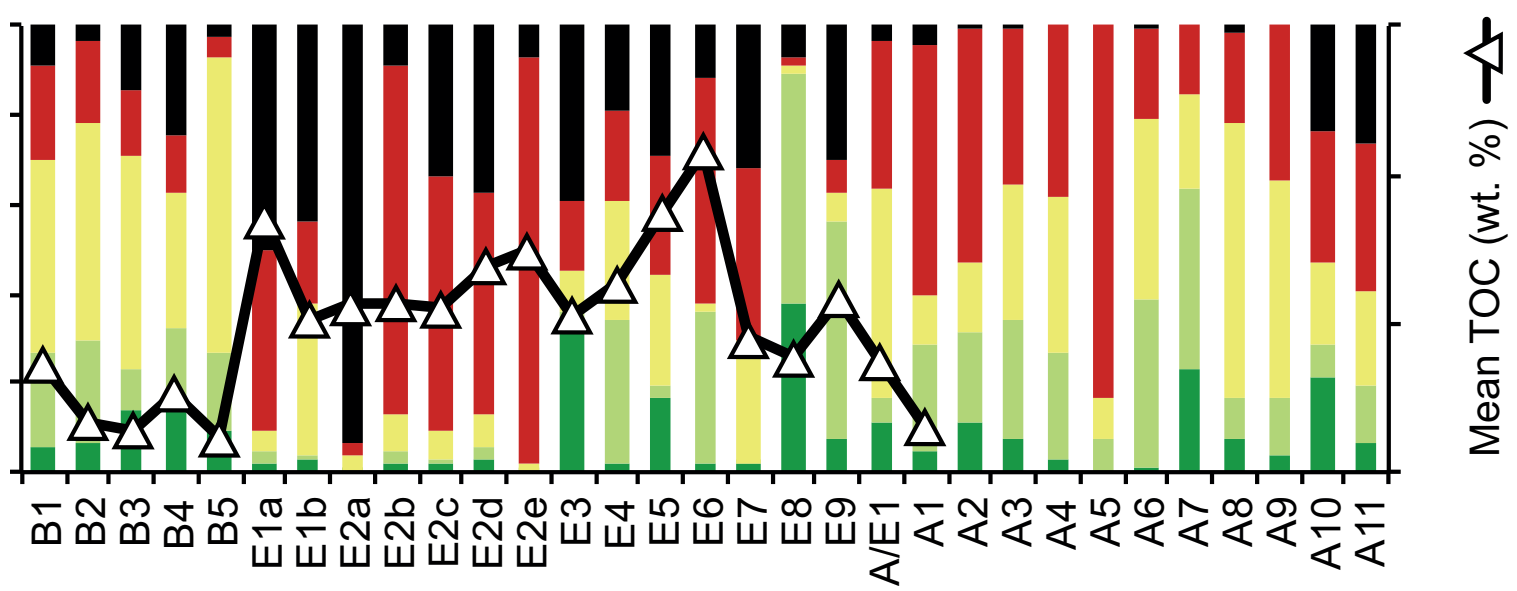

Caswell, Frid and Borja 2018 Figure 2 colour 
Figure 3
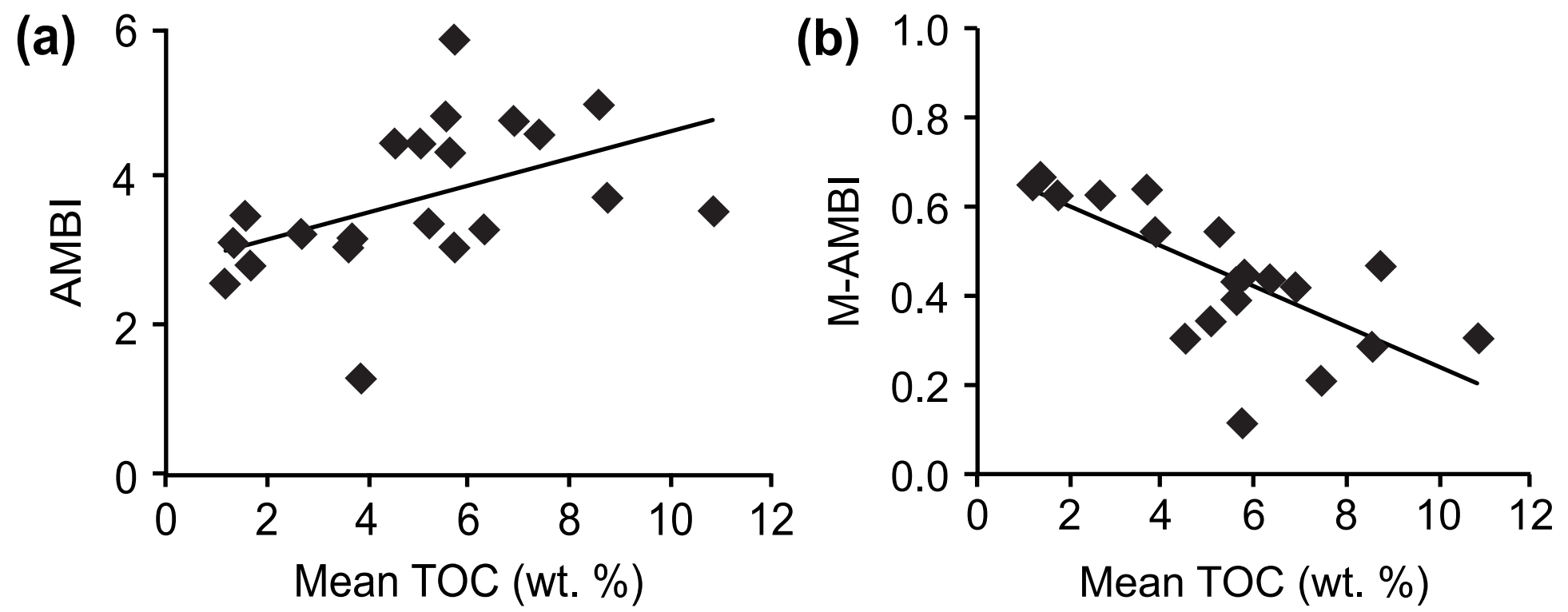

Caswell, Frid, Borja 2018 Figure 3 
Figure 4 colour (online only)

(a)

Ecol. groups:

$\begin{array}{lll}\text { I } & \text { III } \\ \text { II } & \text { IV }\end{array}$

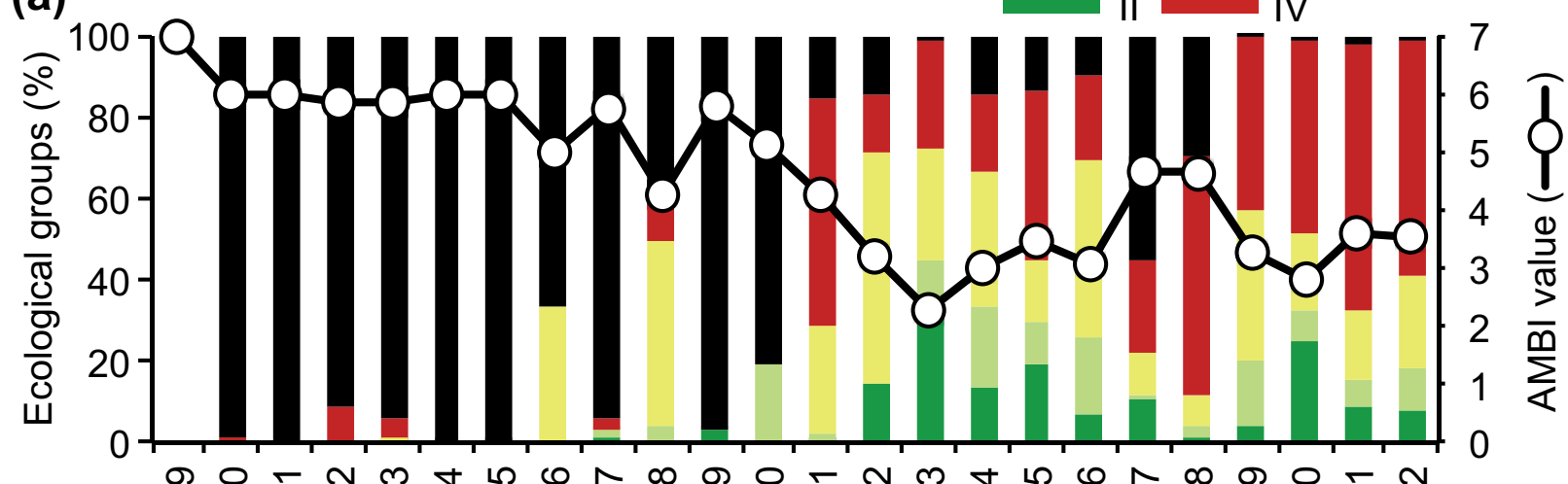

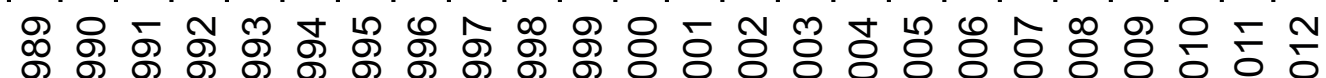

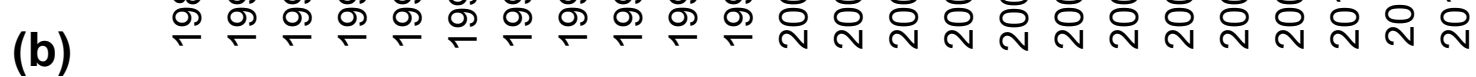

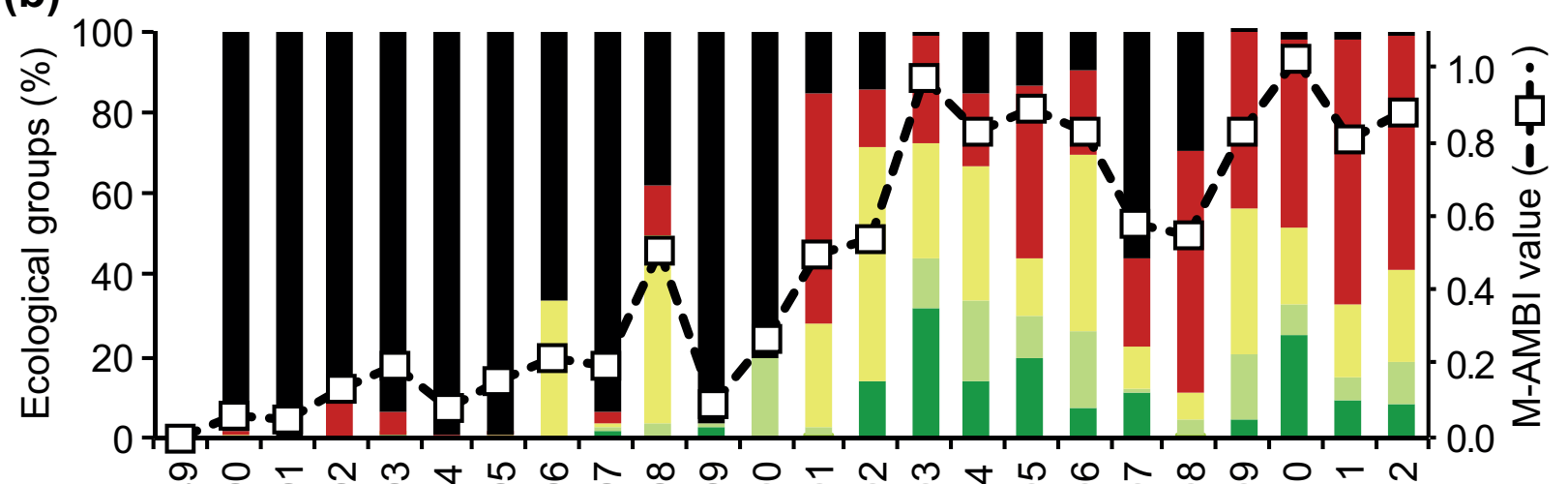

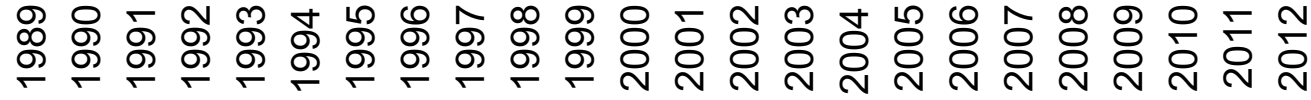

(c)

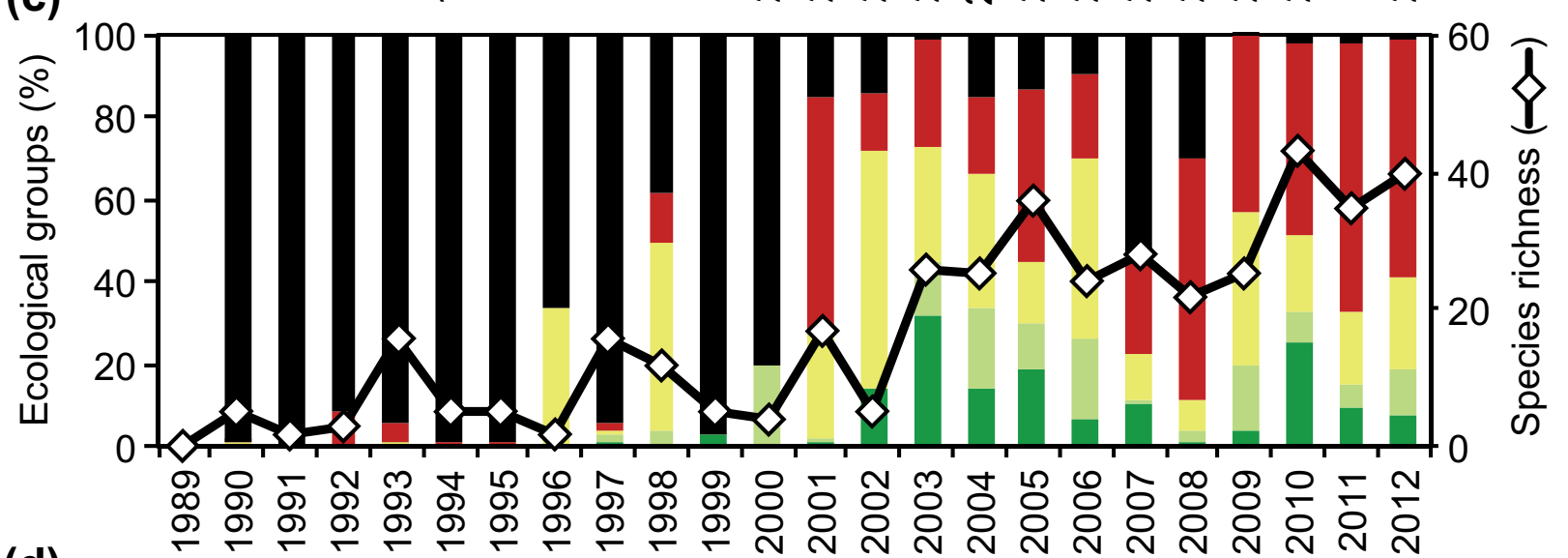

(d)

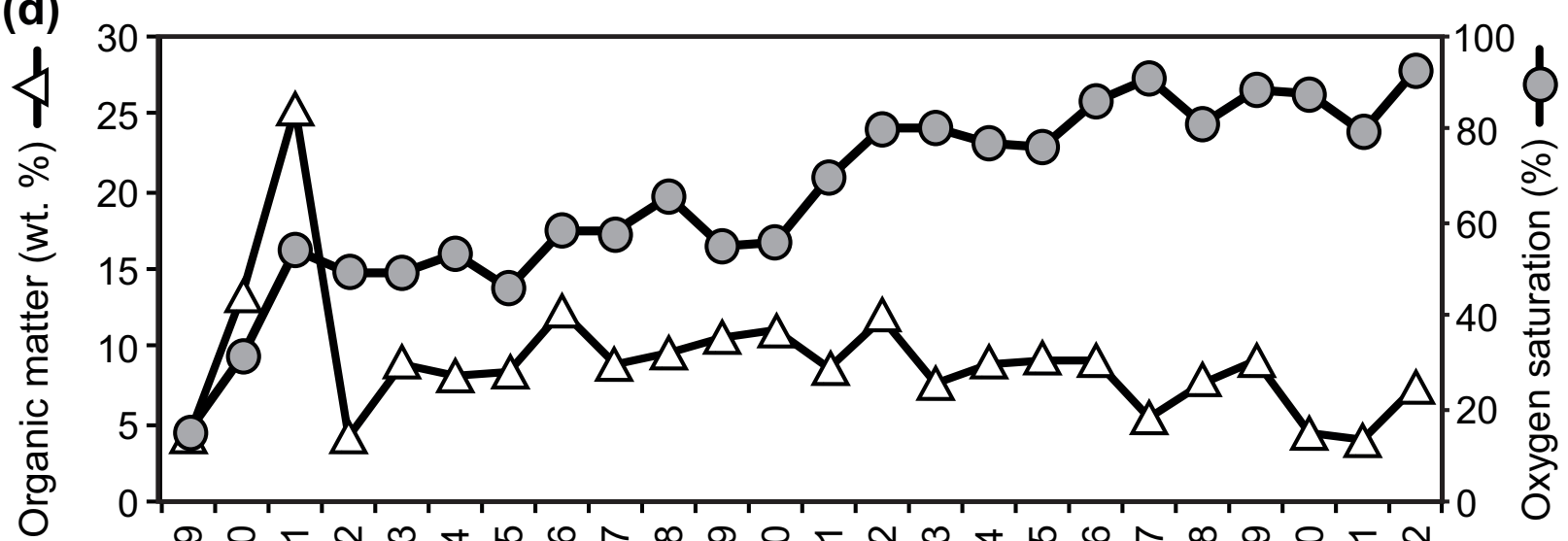

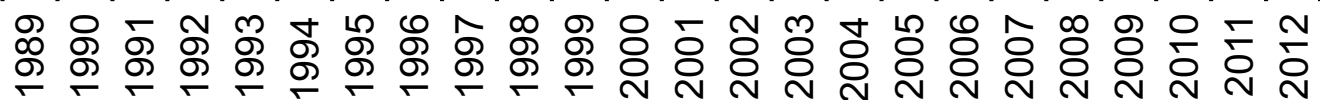

Caswell , Borja, Frid 2018 Figure 4 colour 
Figure 4 black and white

Ecol. groups:

(a)

II

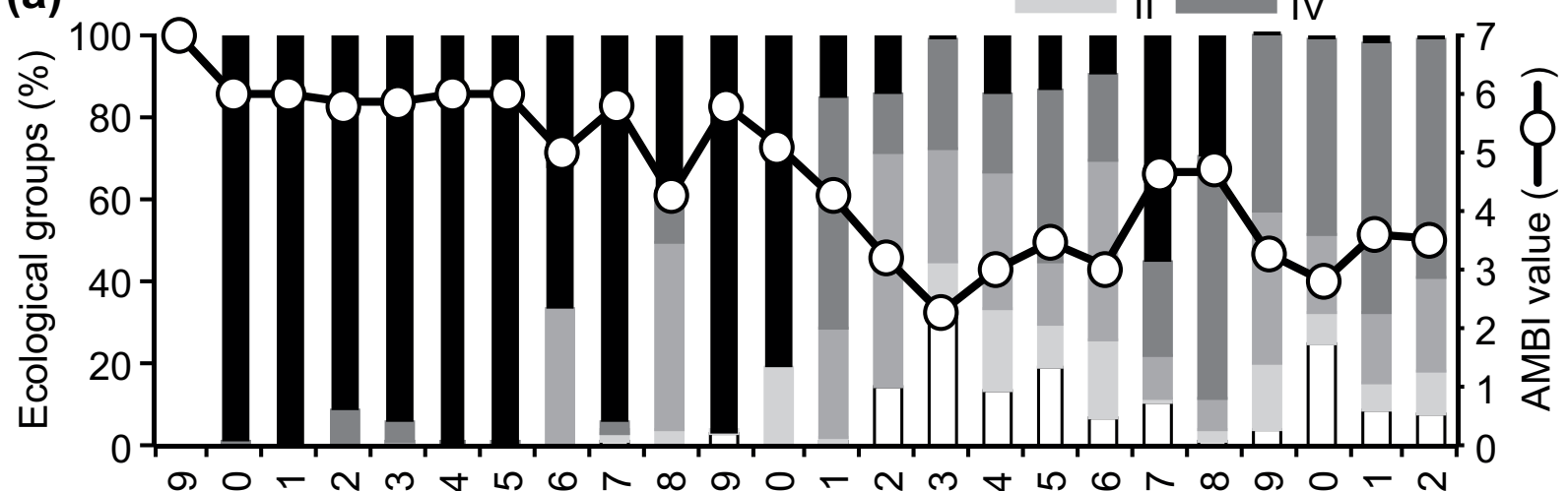

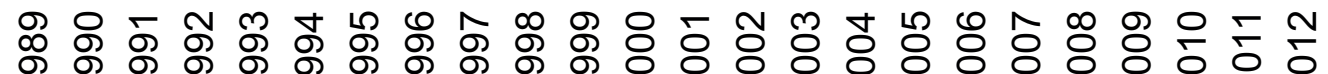

(b)

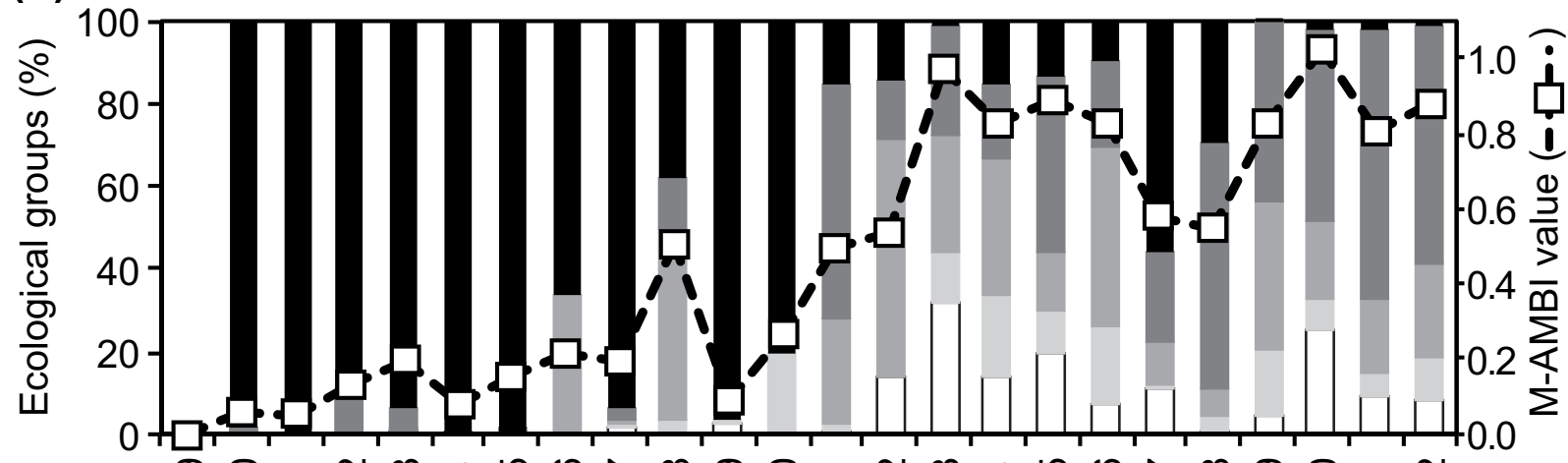

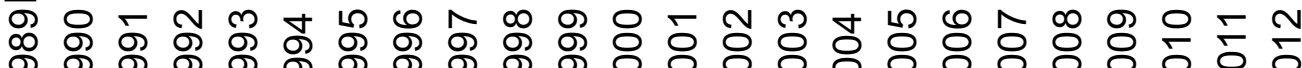

(c) 암 음

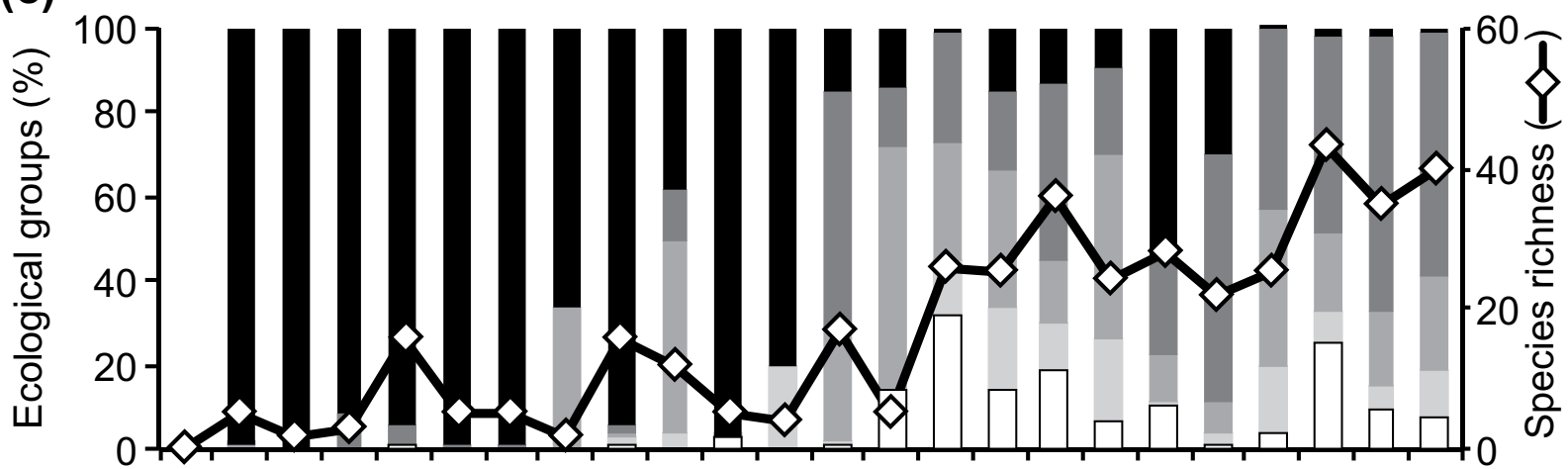

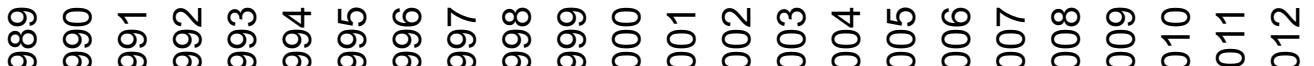

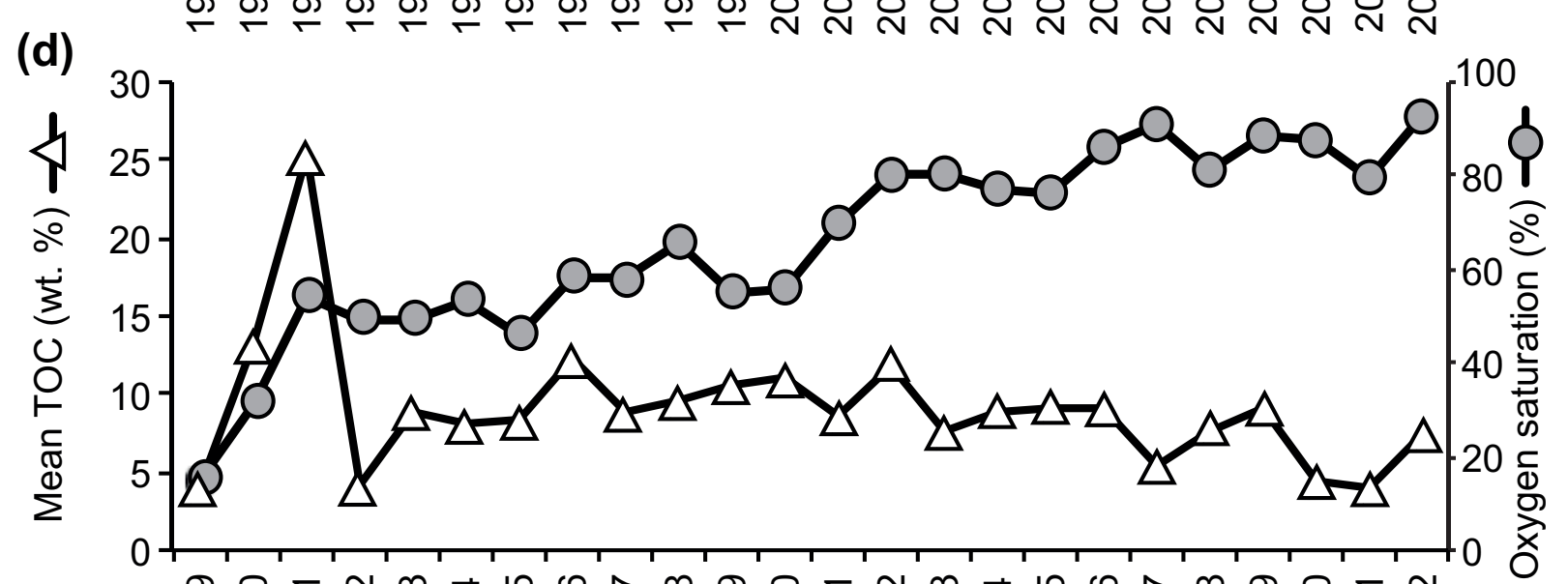

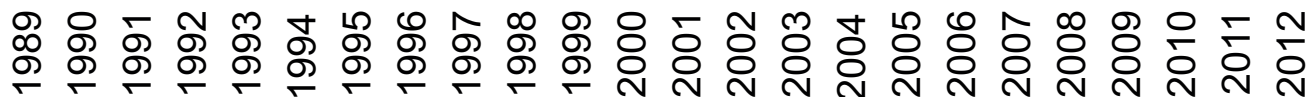

Caswell, Frid, Borja 2018 Figure 4 black and white 
Figure 5 black and white

(a)

Ecol. groups:
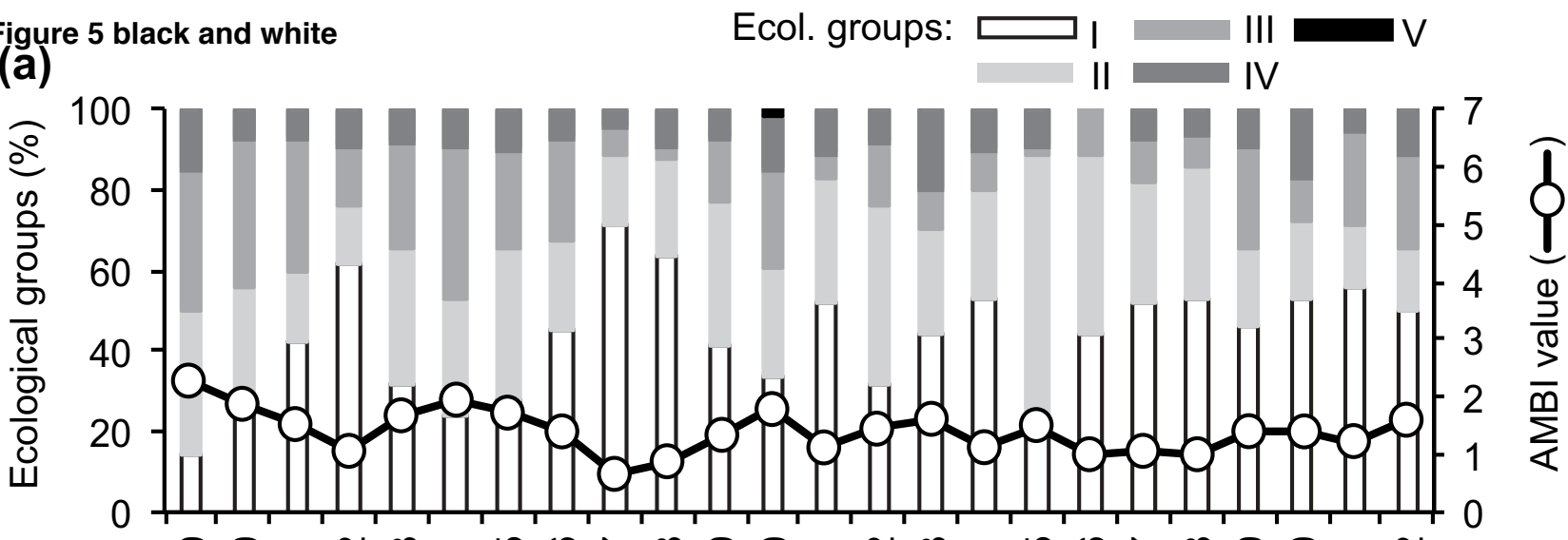

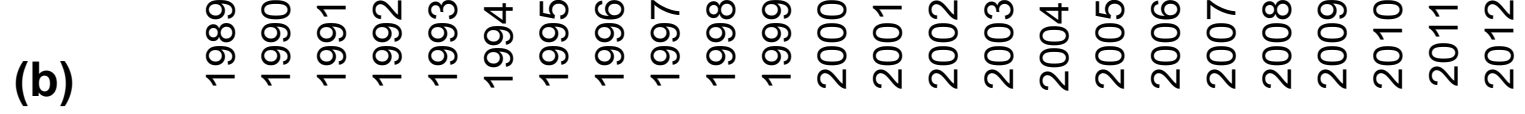

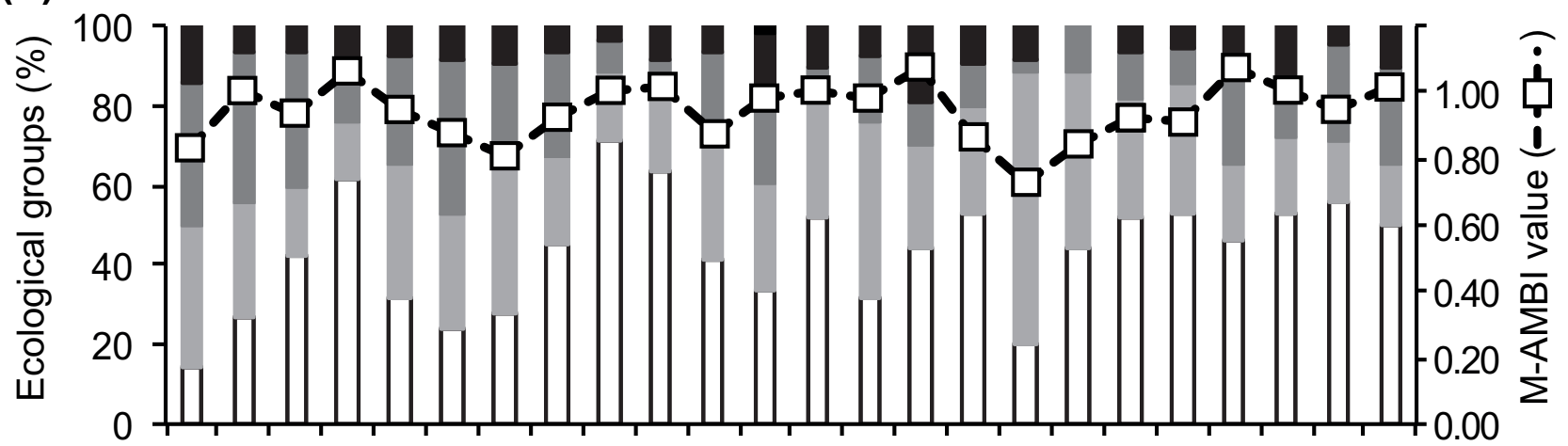

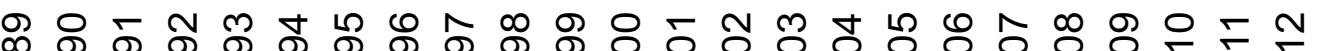

(c)

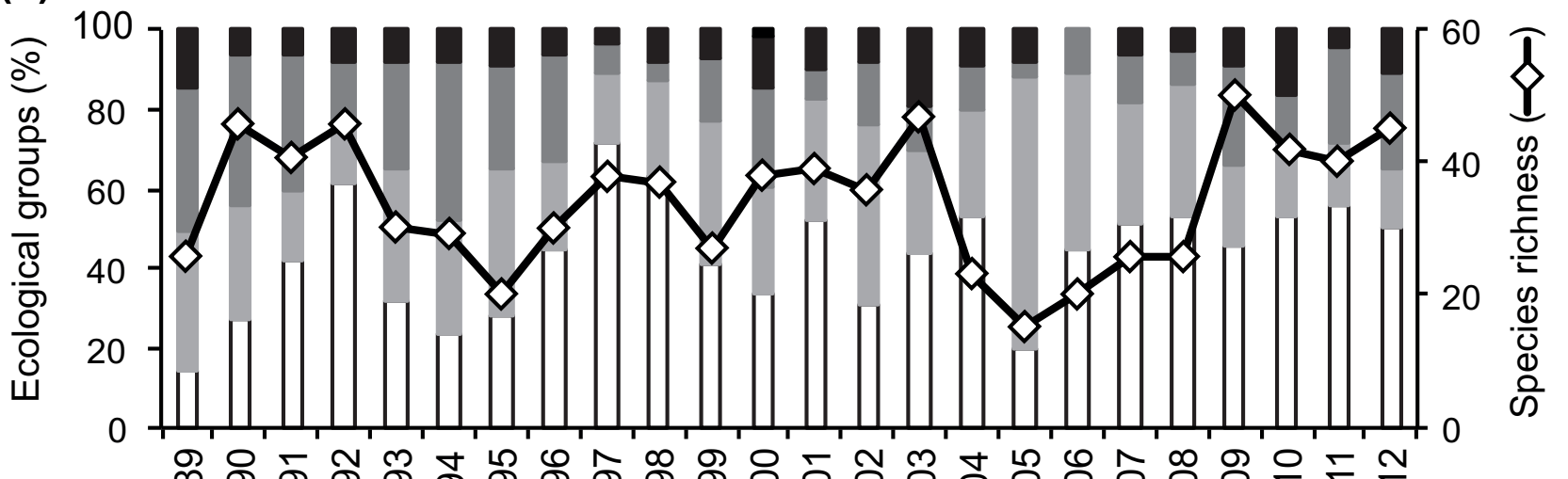

(d)

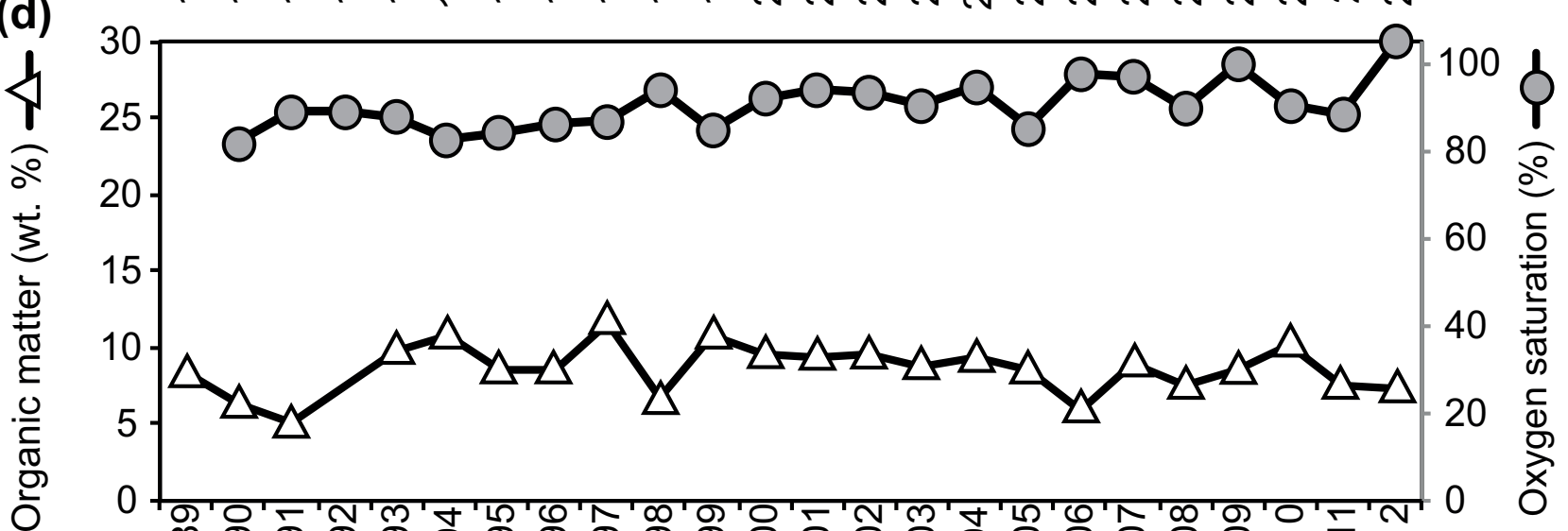
年

Caswell , Borja, Frid 2018 Figure 5 colour 
Figure 5 colour (online only)

(a)

Ecol. groups:

I $=$ III

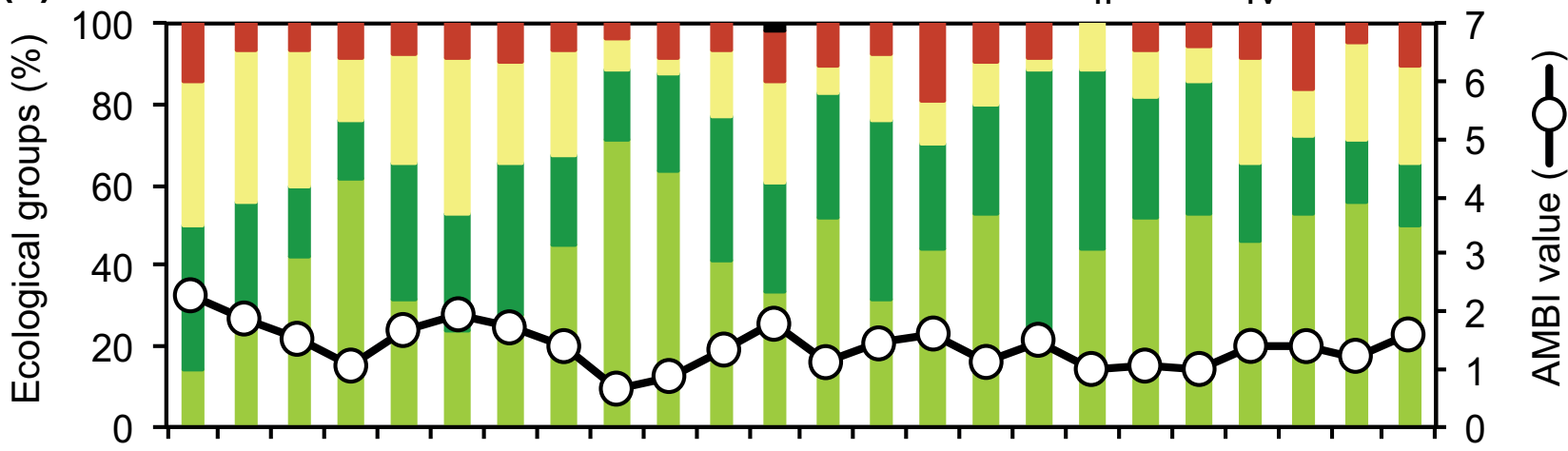

(b) $\quad$ ᄋ 욤

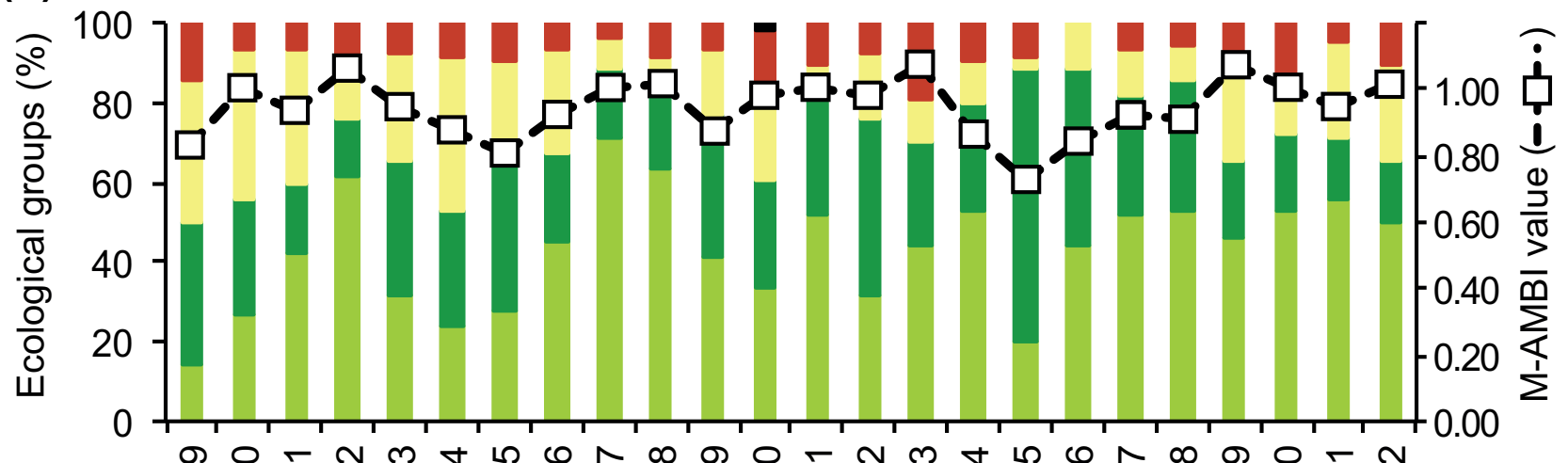

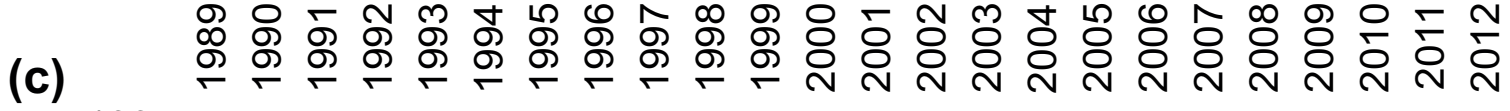

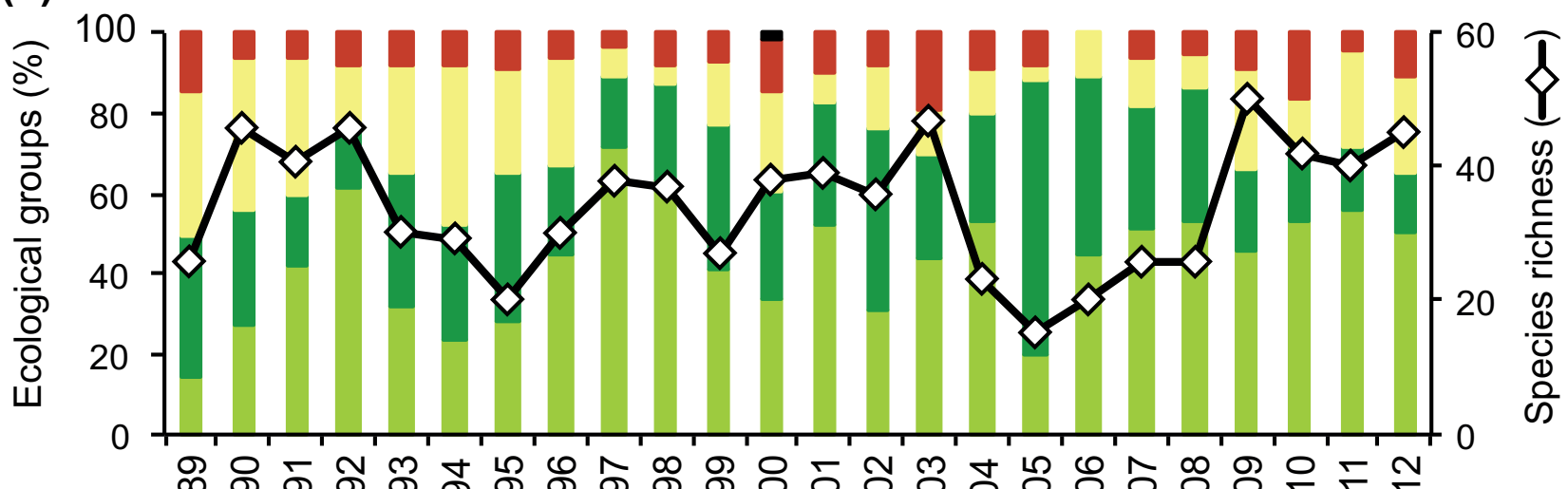

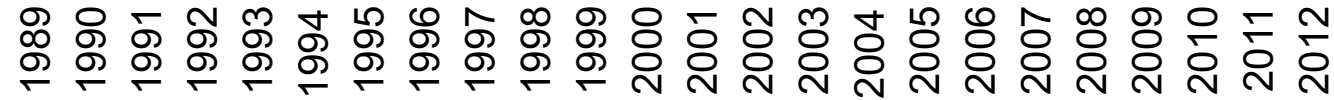

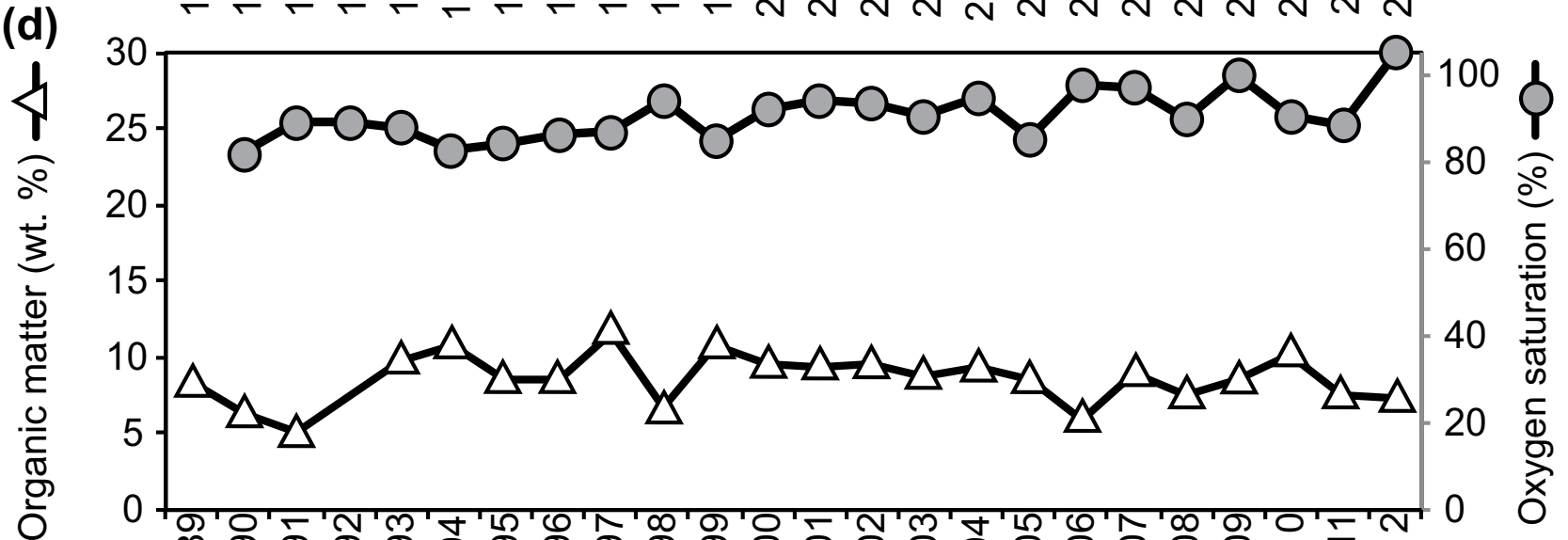

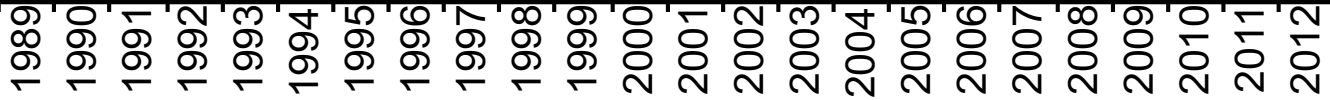

Caswell , Borja, Frid 2018 Figure 5 colour 
Figure 6
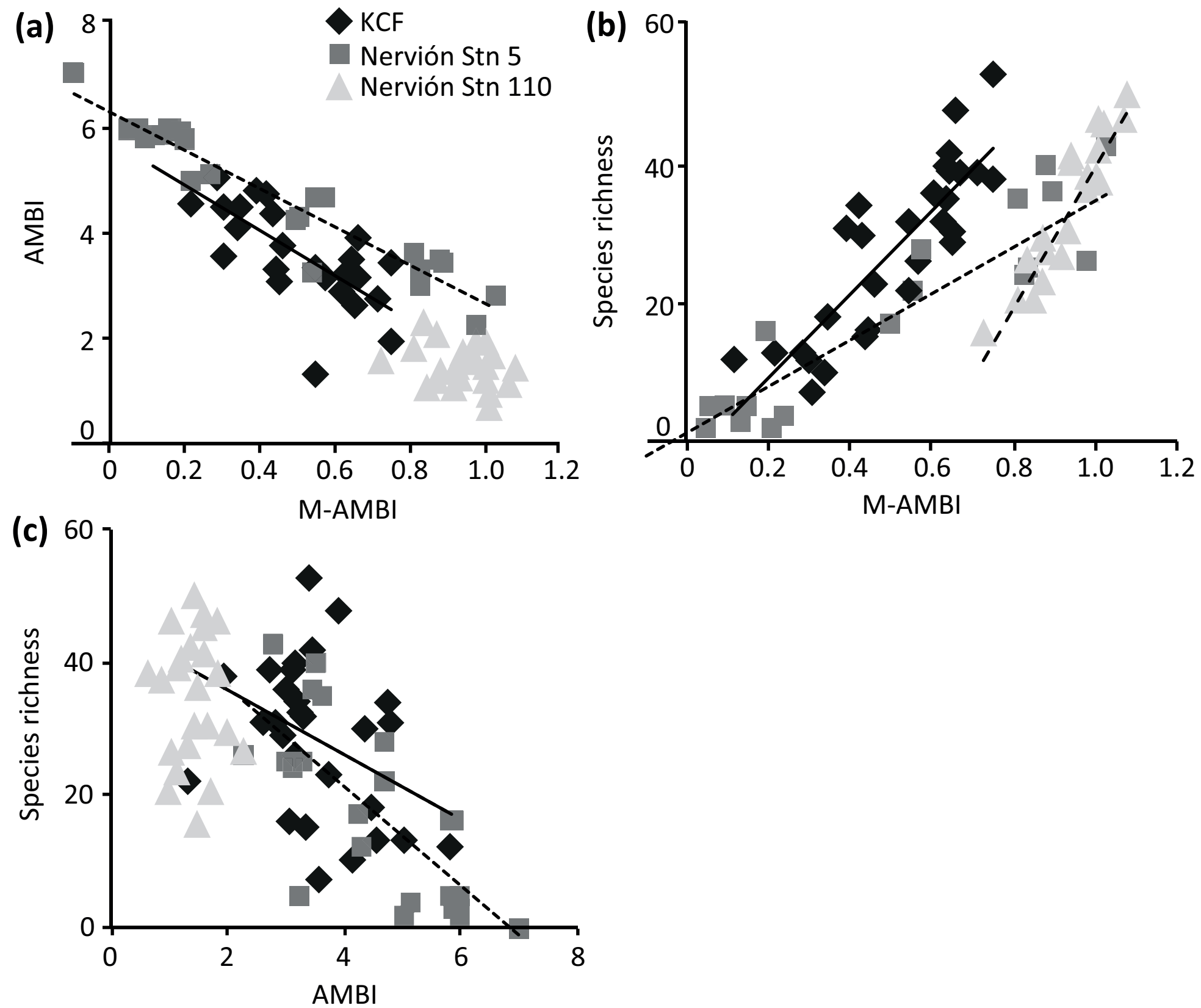

Caswell, Frid, Borja 2018 Figure 6 
Figure 7 colour (online only)

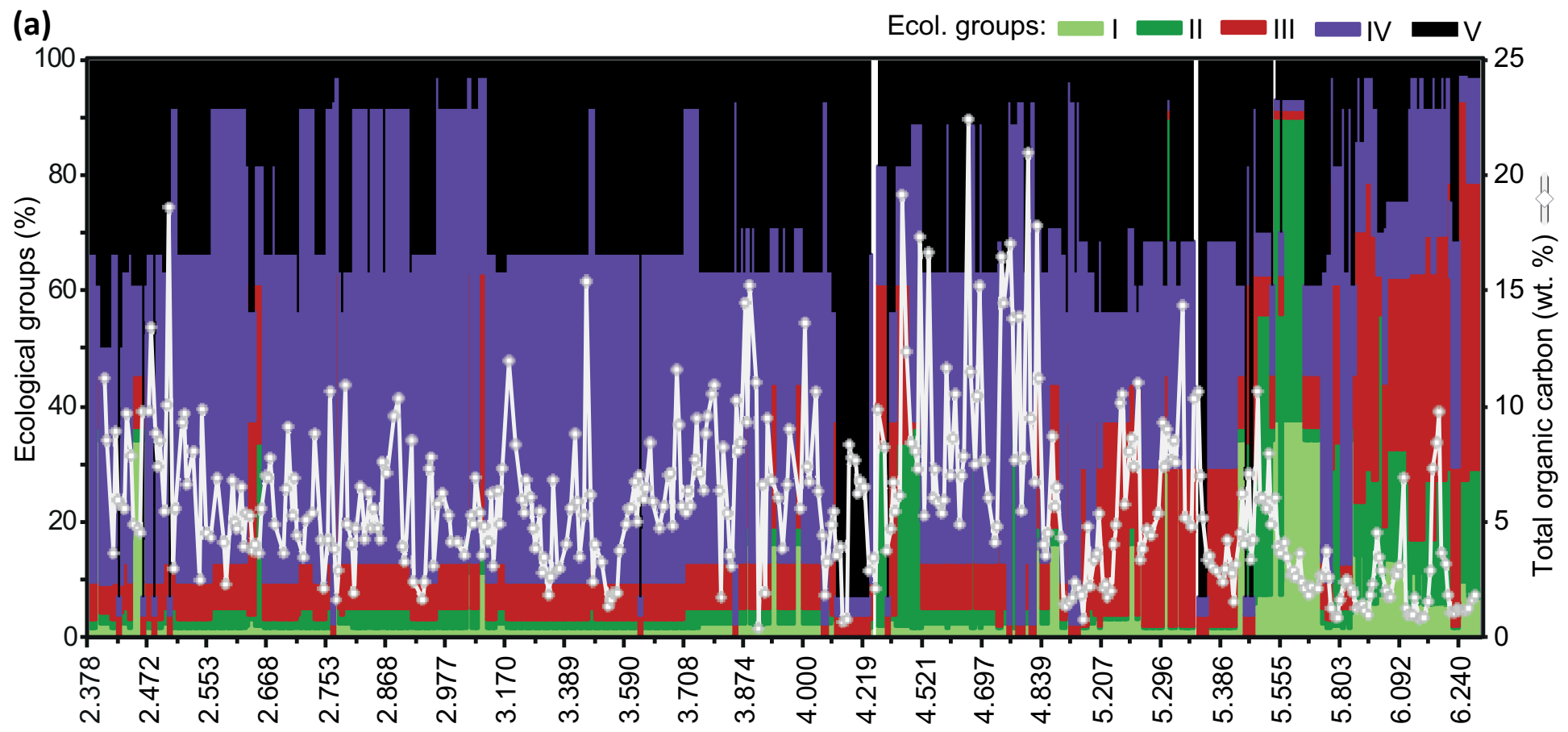

(b) Time (Myr)

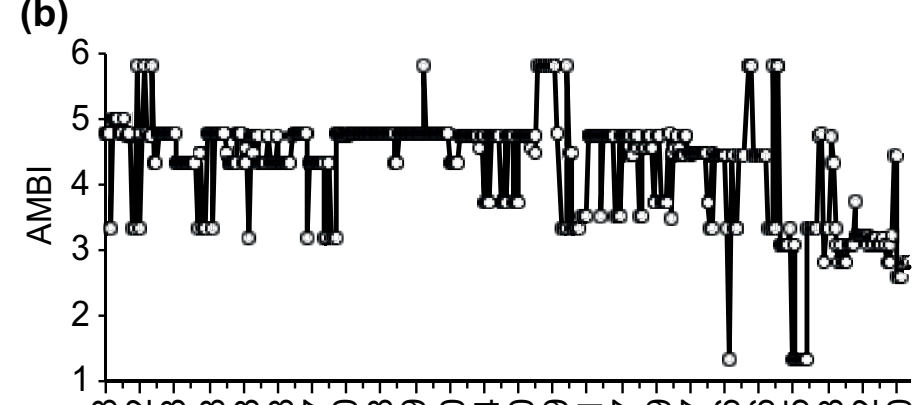

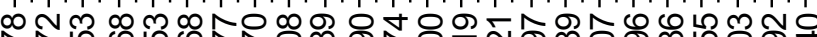
m N N N N N Nm mं m m Time (Myr) (c)

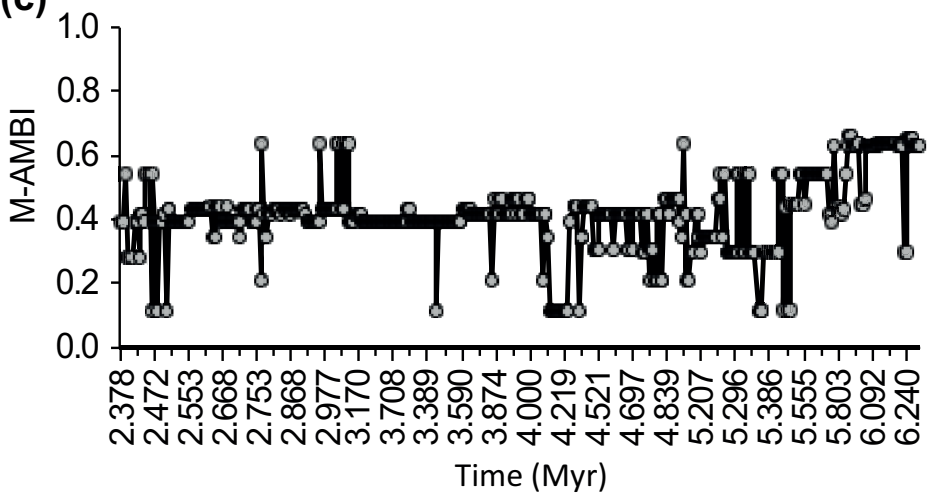

Caswell, Frid, Borja 2018 Figure 7 
Figure 7 black and white

(a)

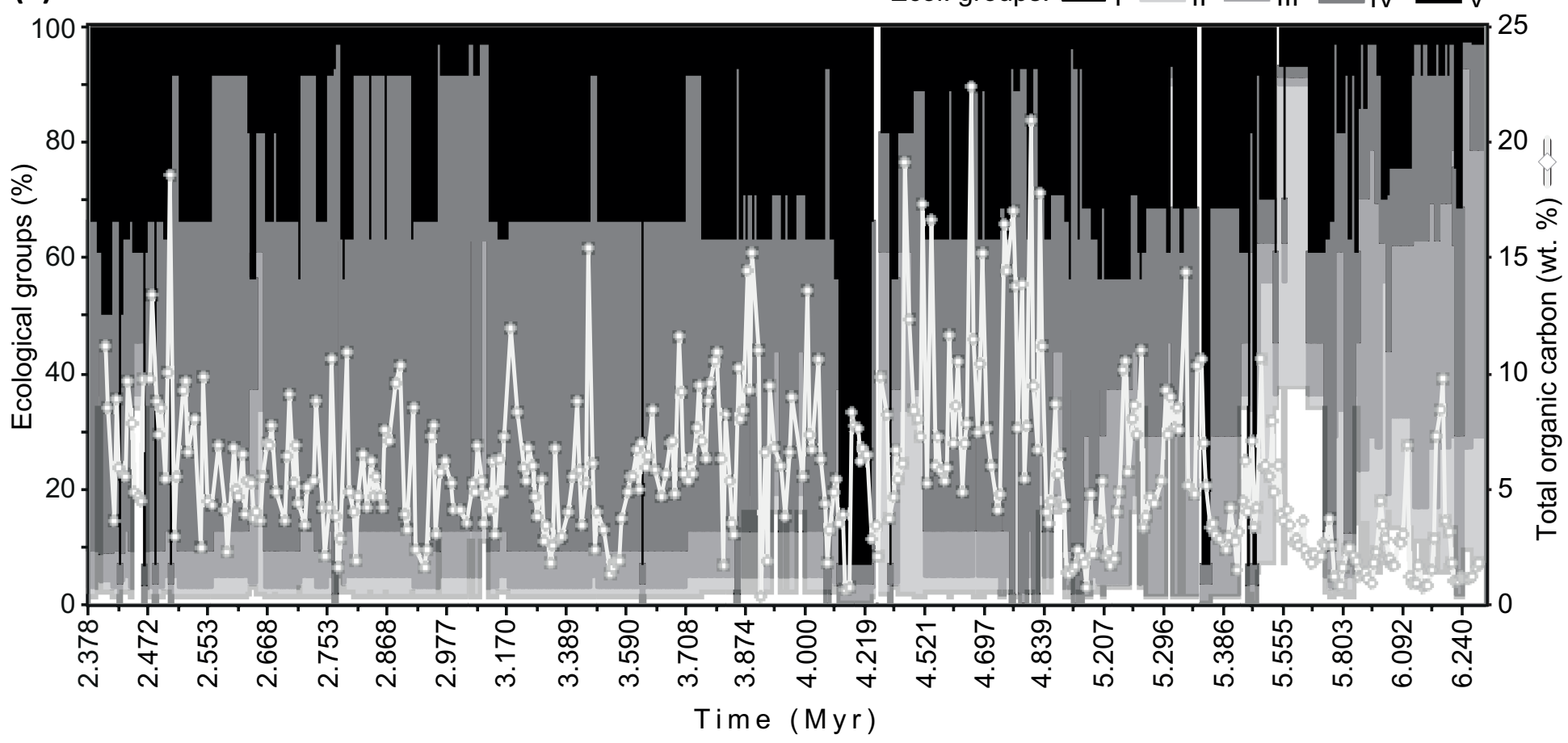

(b)

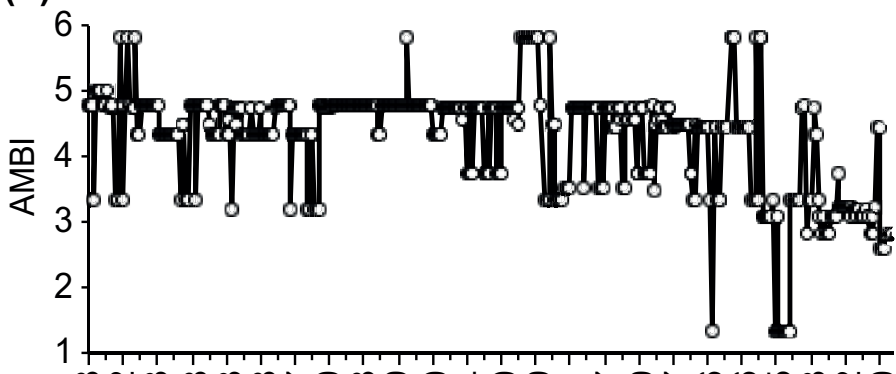

DNM

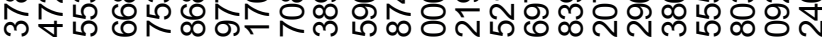

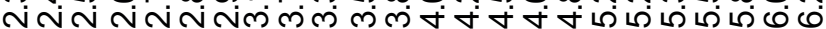
Time (Myr)

Caswell, Frid, Borja Figure 7 black and white

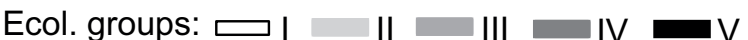

(c)

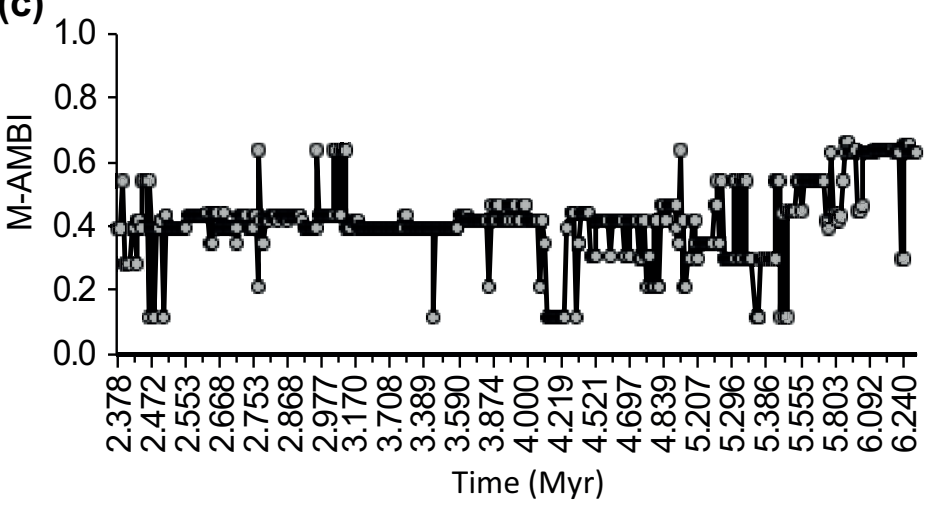


Supplementary Table S1

Click here to download Supplementary Data: Supplementary Table S1.xlsx 
Supplementary Fig. $\mathbf{S 1}$

Click here to download Supplementary Data: Caswell, Frid, Borja 2018 Supplementary Fig. S1.eps 